\title{
An osseous industry dated from the Last Glacial Maximum: the special case of the "Le Colombier" assemblage in Chézy-sur-Marne (Aisne, France)
}

Une industrie en matières osseuses datée du Dernier Maximum Glaciaire : le cas unique de la série du «Colombier» Chézy-sur-Marne (Aisne, France)

\section{Aline Averbouh, Nejma Goutas and Cyril Montoyac}

\section{OpenEdition}

\section{Journals}

\section{Electronic version}

URL: http://journals.openedition.org/paleo/5028

ISSN: $2101-0420$

Publisher

SAMRA

\section{Printed version}

Date of publication: 1 September 2020

Number of pages: 18-35

ISSN: $1145-3370$

\section{Electronic reference}

Aline Averbouh, Nejma Goutas and Cyril Montoyac, « An osseous industry dated from the Last Glacial Maximum: the special case of the "Le Colombier" assemblage in Chézy-sur-Marne (Aisne, France) », PALEO [Online], 30-2 | 2020, Online since 30 September 2020, connection on 26 November 2020. URL http://journals.openedition.org/paleo/5028

\section{(c)}

PALEO est mis à disposition selon les termes de la licence Creative Commons Attribution - Pas d'Utilisation Commerciale - Pas de Modification 4.0 International. 
REVUE D'ARCHÉOLOGIE PRÉHISTORIQUE

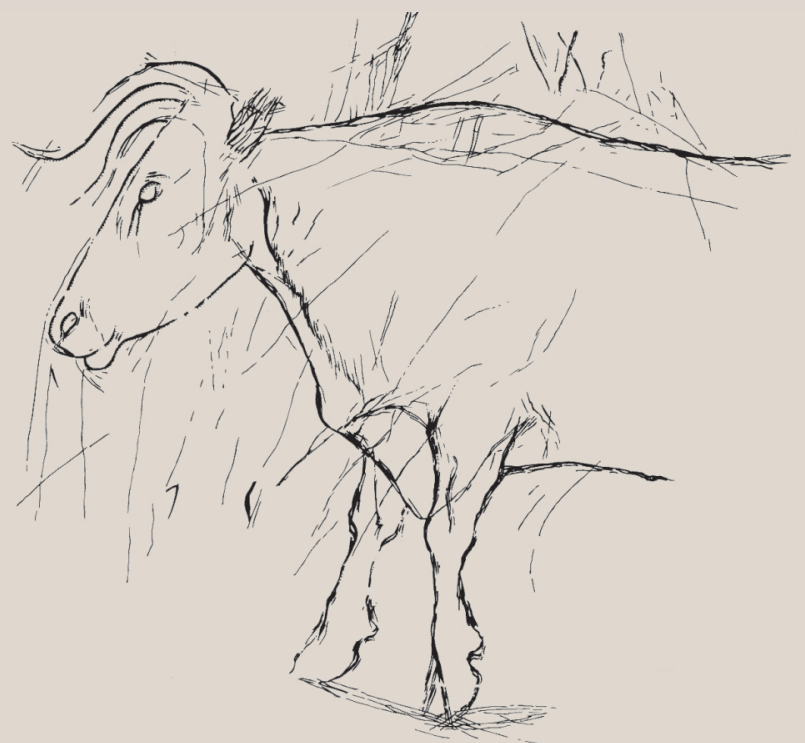


AN OSSEOUS INDUSTRY

DATED FROM THE LAST

GLACIAL MAXIMUM:

THE SPECIAL CASE OF

THE "LE COLOMBIER"

ASSEMBLAGE IN

CHÉZY-SUR-MARNE

(AISNE, FRANCE)

Aline Averbouha,

Nejma Goutas

Cyril Montoyac

a. CNRS - MNHN UMR 7209 AASPE, Archéozoologie, Archéobotanique:

Sociétés, pratiques et environnements, Muséum national d'Histoire naturelle, Département Homme \& Environnement, CP 56, 55 rue Buffon,

FR-75005 Paris - aline.averbouh@mnhn.fr

b. CNRS - UMR 7041 ArScAn, équipe Ethnologie Préhistorique, Maison de l'Archéologie et de l'Ethnologie René Ginouvès, 21 allée de l'Université

FR-92023 cedex, Nanterre-nejma.goutas@cnrs.fr

c. Ministère de la Culture, DRAC Occitanie, Service régional de l'archéologie,

5 rue Salle l'Evêque, CS 49020, FR-34967 Montpellier cedex 2 et Aix-Marseille Université, CNRS, LAMPEA, UMR 7269, Aix-en-Provence -

cyril.montoya@culture.gouv.fr

PALEO 30 | t. 2

JUILLET 2020

PAGES 18 À 35

KEY-WORDS Last Glacial Maximum, Chézy-sur-Marne, France, Osseous industry, perforated baton, waste products.
Located in the south-east of Picardy in the Aisne, the open-air site of «Le Colombier» allows us to reevaluate our knowledge of the human occupation of northern Europe during the Last Glacial Maximum. Thanks to the many and varied remains it contains, it offers a rare opportunity to collect information on the behaviour developed by these poorly known societies from the early Upper Palaeolithic period in northern France. This is particularly the case of the assemblage of bone industrie, whose small number ( 5 items divided into waste and tools) is counterbalanced by its strong typological-technological coherence and by the presence of pieces that could attest that the occupants of Chézy-sur-Marne transformed reindeer antler according to principles that differed from those of contemporary Badegoulian groups in south-western France. 
Une industrie en matières osseuses datée du Dernier Maximum Glaciaire : le cas unique de la série du « Colombier » Chézy-sur-Marne (Aisne, France)

Localisé au sud-est de la Picardie dans l'Aisne, le site de plein air du «Colombier » permet de réévaluer nos connaissances sur l'occupation humaine de l'Europe septentrionale au Dernier Maximum Glaciaire. Grâce aux vestiges nombreux et variés qu'il renferme, Il offre l'opportunité rare de recueillir des informations sur les comportements développés par ces sociétés, mal connues, du Paléolithique supérieur ancien du nord de la France. C'est notamment le cas du petit ensemble d'industrie osseuse dont le faible nombre ( 5 pièces réparties en déchets et outils) est contrebalancé par sa forte cohérence typo-technologique et par la présence de pièces qui pourraient attester que les occupants de Chézy-sur-Marne ont transformé le bois de renne selon des principes différents de ceux des groupes contemporains badegouliens du sud-ouest de la France.

\section{INTRODUCTION}

In 2012, two pieces related to elements of the bone industry were discovered at the «Le Colombier» site at Chézysur-Marne (Aisne, France) occupied during the Last Glacial Maximum. During the following campaigns, 2013 and 2014, three new artefacts were discovered and could be integrated into this set. To date, the series therefore consists of five pieces: four, made of reindeer antler, are waste products or proven tools; one, made of bone, raises questions about its status as a tool or butchery waste. All of them show technical and typological particularities that give, for this period in the north of France, a new character to this assemblage. It therefore seemed useful to us to make a detailed analytical presentation of it, which is the subject of this article.

\section{1 | THE SITE}

The « Le Colombier » open-air site is located in the southeast of Picardy, more precisely in the south of the department of Aisne, at an equal distance between Paris and Reims (fig.1), in the municipality of Chézy-sur-Marne (Aisne) about $7 \mathrm{~km}$ southwest as the crow flies from Château-Thierry. It is located at the top of a hillside, at an altitude of about $100 \mathrm{~m} \mathrm{NGF}$ on a slight flatness of a promontory overlooking the Marne valley, at the confluence of the latter with its tributary, the Dolloir. The archaeological diagnosis carried out in a preventive framework by Clément Paris in November 2010 confirmed the existence of an open-air occupation of the early Upper Palaeolithic and made it possible to limit, from a sedimentary point of view, the potential extension of the deposit over an area of approximately $1,300 \mathrm{~m}^{2}$ (Paris et al. 2011). Four planned excavation campaigns (2011 to 2014) have made it possible to study nearly $70 \mathrm{~m}^{2}$ and collect about 5,000 pieces, several of which are associated with anthropogenic layouts (fig. 2)

Most of the sedimentation is represented by laminated brown silts of the Middle Pleniglacial (55-35 ka BP) capped by carbonate deposits of the Upper Pleniglacial (35-15 ka $\mathrm{BP})$. These are kept only at the top of the slope. It is within these that the site of Chézy-sur-Marne «Le Colombier» is located, between 40 and $80 \mathrm{~cm}$ deep. Initially, two archaeological levels had been identified at the excavation on altimetric bases. It turns out out after analyses and reassembly that the small batch of pieces identified (50 pieces) as level $A$, is the probable result of a solifluction phenomenon. Level $B$ is the main level of the site, which is distributed from a double depression: a small $10 \mathrm{~m}^{2}$ basin with two equipped fireplaces, and a vast depression whose limits are not yet known (fig.2). The two sectors have been linked by numerous refittings concerning several categories of remains (lithics, fauna, shells).

Nine AMS dates - ranging from 23,582-22,952 intCal13 $(19,320 \pm 100 \mathrm{BP})$ to $20,711-20,303$ Cal.BP intCal13 (17,010 \pm 60 BP) - are currently available, making the Chézy-surMarne «Le Colombier» one of the few sites of the ancient Upper Palaeolithic in northern France dated to the Last Glacial Maximum (Montoya et al. 2019). At present, it is also the most northernly dated site in France for this period. It thus offers a rare opportunity to collect information on 


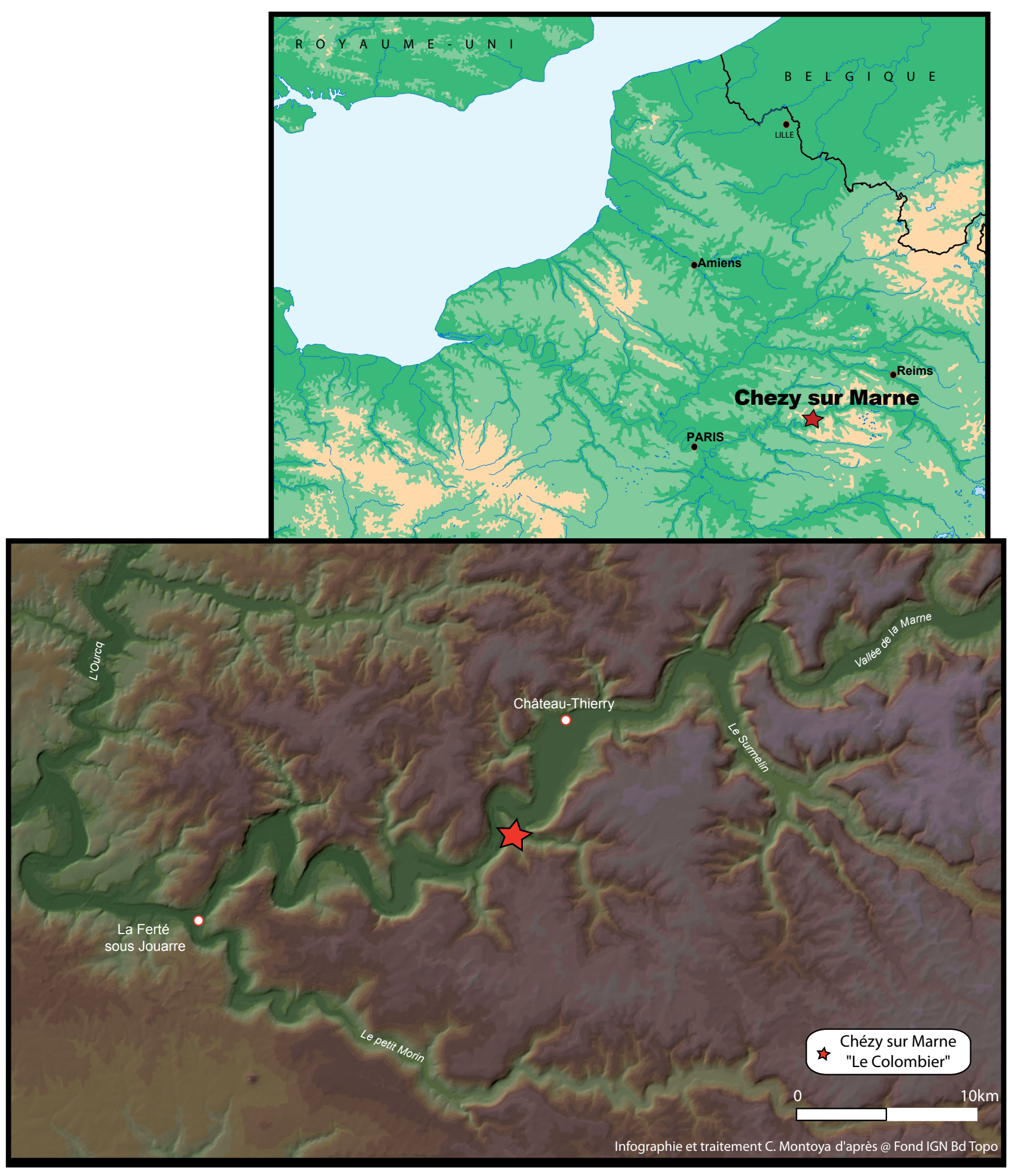

- FIGURE 1 -

« Le Colombier », Chézy-sur-Marne (Aisne, France). Site localization (Computer graphics C. Montoya in Montoya et al. 2019).

the behaviours developed by these poorly known societies from the early Upper Palaeolithic period in northern France (Montoya et al. 2019; Montoya et al. in press) and to reassess our knowledge of the human occupation of northern Europe at the Last Glacial Maximum, by completing the only site previously known of Wiesbaden-Igstadt in Germany (Street and Terberger 1999; Terberger 2013).
"Le Colombier », Chézy-sur-Marne (Aisne, France). Localisation du site (infographie C. Montoya in Montoya et al. 2019).

The many faunal remains - where reindeer and horse predominate 1 - were left between spring and autumn. Lithic production ${ }^{2}$, structured around operational

[1] Studied by 0. Bignon and published in Montoya et al. 2019 [2] Studied by C. Montoya and published in Montoya et al. 2019 


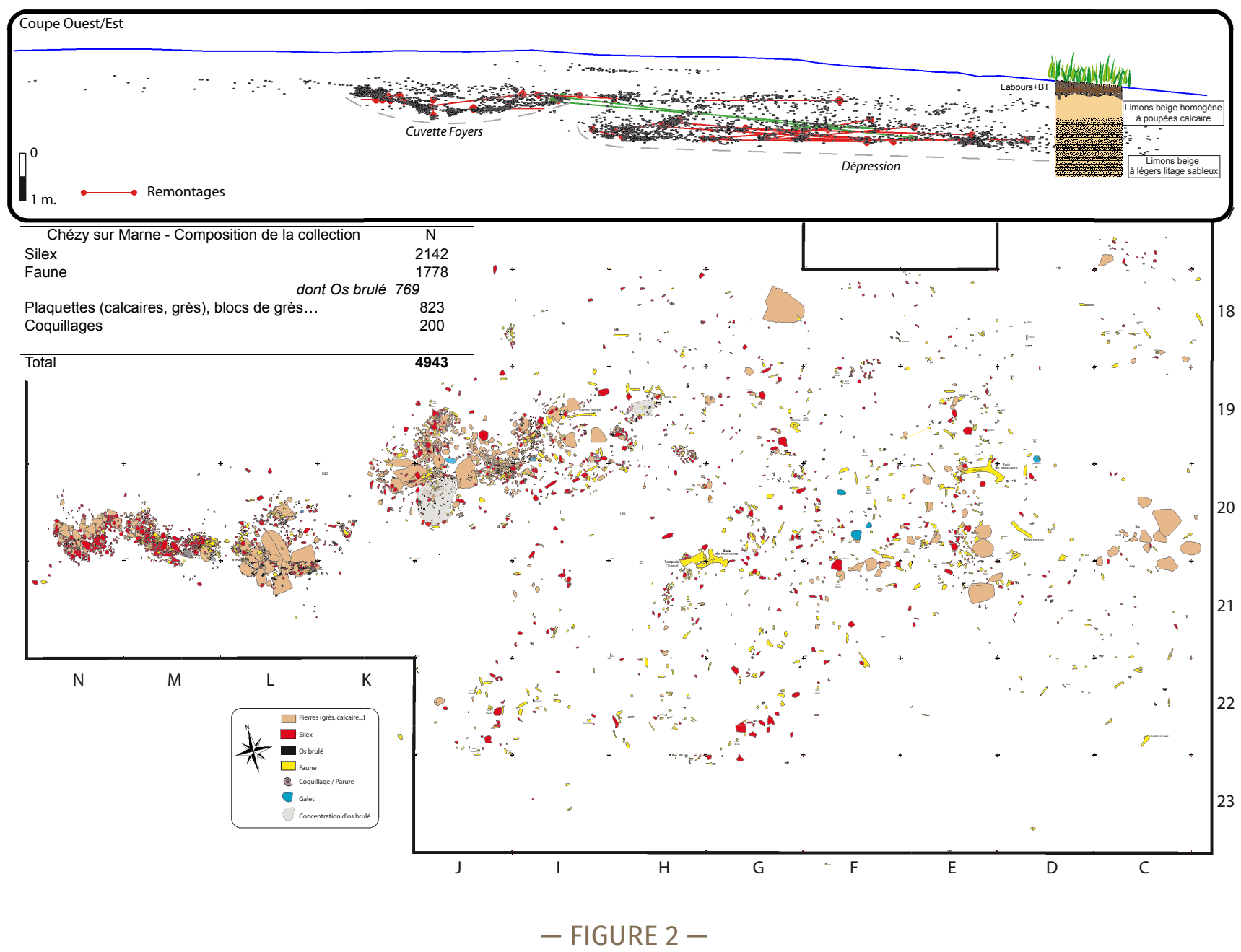

« Le Colombier », Chézy-sur-Marne (Aisne, France). Plan and section (Computer graphics C. Montoya).

sequences, essentially provided retouched tools with many transverse burins recognized as multifunctional tools (for cutting, scraping, grooving ${ }^{3}$ ), mainly involved in the processing of secondary animal resources (bone materials and treated skins). The shell ornament industry ${ }^{4}$ is divided into ornamental elements (gastropods and scaphopods) or tools (large cardium). Finally, the analysis of combustion structures ${ }^{5}$ indicates heating temperatures between 300 and $600^{\circ} \mathrm{C}$ and, for the main fireplace $(\mathrm{KL} / 20-21)$, the existence of at least three operating episodes. In the end, the prehistoric occupation of « Le Colombier » appears to be closely correlated to the presence of many resources offered by the sector: flint, limestone, marl and sandstone deposits, shell outcrops of the Lutétien and Bartonien, migratory passages of mammalian fauna strategically observed by the dominant position of the site in the Marne valley (Montoya et al. 2019).

[3] Studied by A. Pasquini and published in Montoya et al. 2019 [4] Studied by C. Peschaux and published in Montoya et al. 2019 [5] Studied by G. Dumarçay and published in Montoya et al. 2019
"Le Colombier », Chézy-sur-Marne (Aisne, France). Plan de la fouille et sectionprojection Ouest/Est. Les lignes matérialisent les remontages (infographie c. Montoya).

In addition to these activities, there also is the processing of bone materials, as evidenced by the bone industry artifacts.

\section{2 | THE « LE COLOMBIER » OSSEOUS INDUSTRY SERIES}

\section{1 | Composition of the series}

Of the five pieces in the series, only one tool - a perforated baton fragment (CSM2014-n6219-I19) - has been identified. Three other pieces, made of reindeer antler, are waste products : a block in the process of debitage (« matrice » CSM 2014 - n7322 - D20), another possible extraction « matrice » (CSM2012- ${ }^{\circ}{ }^{\circ} 2710-$ GH20), a cut fragment of bez tine- (CSM2014 - n 7117 - D20). The last (CSM2012), in bone, raises questions about its status as a tool or butchery waste.

\section{2 | Status of the pieces}

The pieces studied suffer from alterations of various origins: biological (vermiculations due to the action of plants), mechanical (fractures under the weight of 
sediments, cracks) and chemical (dissolution, manganese or iron deposition, concretion). There is a significant fragmentation of the two pieces found in the eastern part of the excavated area. The perforated baton has suffered a little less from this type of weathering and has a relatively good surface condition. The particular burial context of this tool -in a pit structure, framed on either side by large blocks of stone- will have provided the tool with a «protected environment » favourable to its better conservation.

Despite the general poor surface condition of most of the artifacts, the clairvoyance of the excavation manager who, questioning the presence or not of stigmas of anthropogenic origin, ensured that careful sampling and packaging were carried out to minimise the risks of postselection deterioration is commendable. Moreover, from the first campaign, these remains have benefited, since the dismantling in the field, from a restorationconservation treatment carried out by a professional. It is also worth recalling that, in addition to the proper preservation of bone material, this rapid intervention by a specialist avoids the loss of information and guarantees the best conditions for reading all the technical and nontechnical elements, including the most tenuous ones, that the exhumed parts still carry. The early implementation of this type of provisional measures in the context of planned excavations is sufficiently rare to be highlighted and welcomed here. The other consolidation steps (joining of newly formed fragments) can thus be carried out in complete serenity at a later date.

\section{3 | Methodological principles followed}

Taking into consideration the entire industry, i.e. all the witnesses of the transformation (waste, blanks, roughouts and finished objects), the technological analysis makes it possible to identify and characterize from a technical and economic point of view the different operations of the transformation chains: acquisition and choice of raw material, technical means and methods used (for preparing, blank productioning, shaping, finishing). By combining these data with those collected on the use of finished objects, their repair and abandonment, the entire bone material exploitation chain can be traced, significantly enriching knowledge of the socio-economic systems of these prehistoric peoples. However, the small number of pieces available to date at the Chézy-sur-Marne « Le Colombier » gives an insufficient representation of two major categories of technological analysis -waste and finished objects- to carry out the refitting (by default) necessary for its realization. The absence of the two intermediate categories (blanks and roughouts) only reinforces this observation. It will therefore be necessary to wait for the discovery of other bone industry pieces to conduct such an approach. Nevertheless, each piece contains a great deal of information that can already be used to better define their integration into the site's occupation (acquisition of raw materials, relationship with other industries produced, etc.) and their possible cultural attribution and, consequently, that of the groups that have settled at Chézy.
The pieces of «Le Colombier» were therefore studied by means of a technological reading- that made it possible to characterize, for each piece, its conservation state (taphonomic approach), its raw material (species and anatomical origin, state of freshness at the time of work), its technical stigmatas (type, location, position, extent, organization, orientation) to which are added the macro functional traces for the finished object. Each piece was observed with the naked eye, then under a stereoscopic microscope (Nikon SMZ 1500, magnifications ranging from $\times 3.75$ to $\times 50$ ). All the observations were carried out within the Imaging and Optical Microscopy Department of the Maison Archéologie et Ethnologie, René-Ginouvès, at Nanterre (CNRS USR 3225).

\section{3 | ANALYTICAL DESCRIPTION}

\section{1 | The perforated baton (CSM2014-6219-I19)}

Artifact $n^{\circ} 6219$ could unambiguously be identified as a mesio-distal fragment of a perforated baton (fig.3-1) made from the right antler of a reindeer. Exhumed in 2013 within square 120 (on the edge of 119), this tool was located in a pit structure (IJK 19-21) and was associated with other remains (faunal remains, platelets, thermo-altered sandstone blocks, shell ornaments, flint) forming an elongated nappe that seemed to curve slightly northward (Montoya 2013: 15). The origin, anthropogenic or taphonomic, of the pit-like structure remains to this day undetermined (fig.4).

\subsection{1 | Morphometry and typological assignment}

The perforated baton fragment currently has a length of $339 \mathrm{~mm}$ but, depending on the estimated size of the antler from which it was made, it should not have exceeded $360 \mathrm{~mm}$ in length at the origin. With a subrectangular contour, it forms an elongated, wide and thick cylinder 21 and $19 \mathrm{~mm}$ in its mesial part with a maximum width and thickness in its distal part of 32 and $21 \mathrm{~mm}$. Its profile is slightly curved.

The attachment of this perforated baton to one of the types defined by the nomenclature commission on the prehistoric bone industry (Peltier 1992a, b and c) is impossible given its fragmentary state. Indeed, a functional fracture, to which we will return later, deprives us of a significant part of the distal part. However, the anatomical portion selected for its manufacture makes it possible to exclude a connection to the category of perforated baton with " two divergent horizontal branches ». It could either be a " perforated baton with a short branch or without a branch » or « with one or two oblique branches ».

The broken distal part (perforated area) can only be described partially, but it can be argued, in comparison with other parts and depending on the part still present, that the perforation should have a subcircular or subovalar contour. The profile of the perforation chimney (in axial section) is formed by two asymmetric wear planes (fig. 5). The lips of the perforation are blunt, rounded and deformed by use (see below). The mesial part is kept over a long length (nearly $300 \mathrm{~mm}$ ). It is $21 \mathrm{~mm}$ wide and $19 \mathrm{~mm}$ 


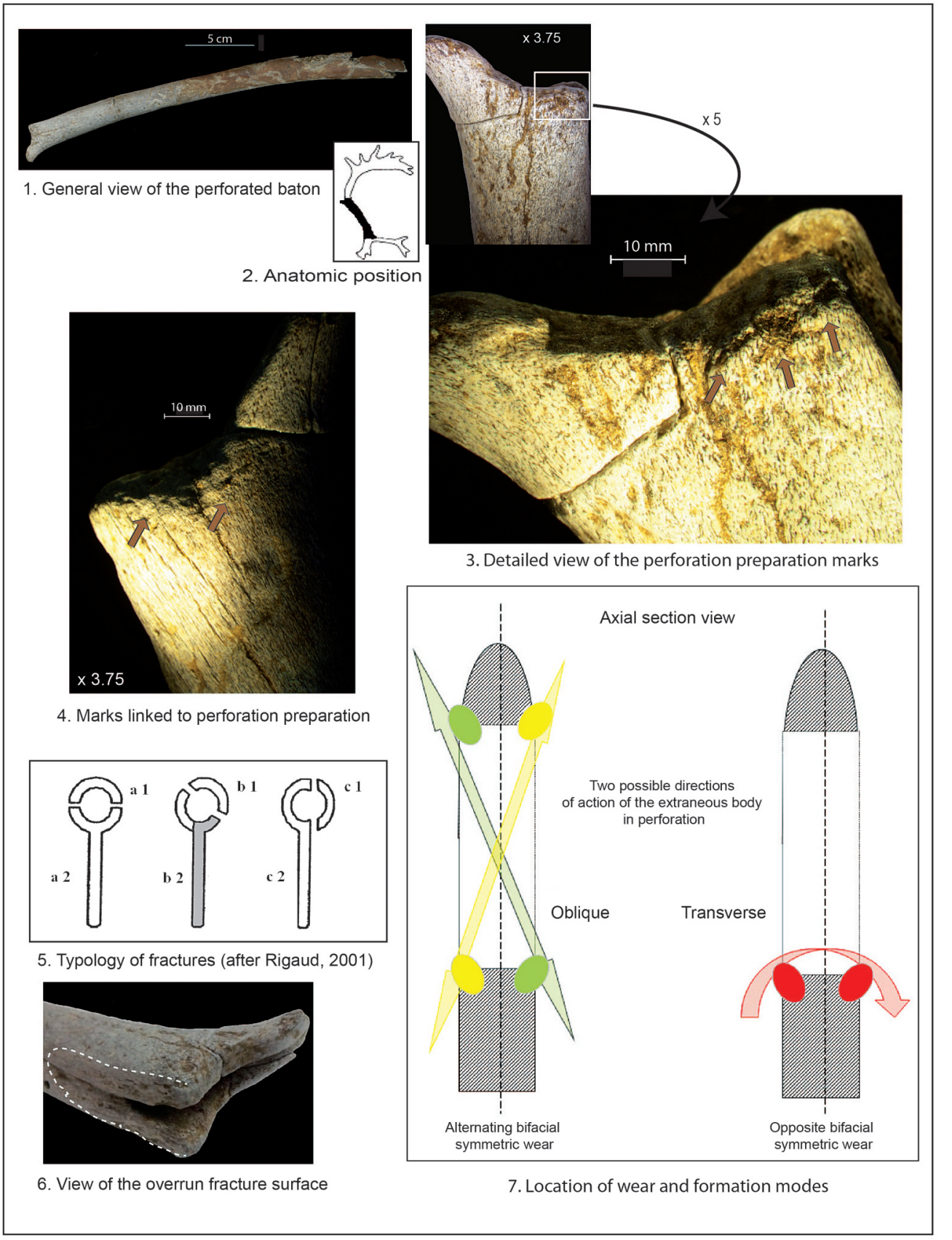

\section{FIGURE 3}

« Le Colombier », Chézy-sur-Marne (Aisne, France). Fragmentary perforated baton of Chezy (part $\left.n^{\circ} 6219\right)$ : general view after restoration, view of details of manufacturing and use stigmatas (photos and computer graphics N. Goutas).

"Le Colombier », Chézy-sur-Marne (Aisne, France). Bâton percé fragmentaire de Chézy (pièce $n^{\circ}$ 6219): vue générale après restauration, vue de détails de stigmates de fabrication et d'utilisation (clichés et infographie N. Goutas).

thick. Its section is oval and its profile slightly curved. The proximal part is absent, eliminated by a post-depositional fracture still visible on the tip of the mesial part.

\subsection{2 | Raw material and technical elements}

The blank used corresponds to a segment of beam cut under the bez tine and above beam B (fig. 3-2). The perforation was made on the beam, at the junction area with the bez tine. In the absence of the basilar part, it is not possible to determine whether it is a massacre or a shed antler. The dimensions of the A/B beam (l: $348 \mathrm{~mm}$; circumference: $70 \mathrm{~mm}$; thickness of compact fabric : $3 \mathrm{~mm}$ ) allow this antler to be classified as a medium size class(adult female or subadult male).

The technical stigmatas created by the blank production process is no longer visible. As this is a «volume blank» (which kept the entirety of its original section), we can only rule on the fact that its production incorporates a transformation scheme by segmentation (Averbouh 2000). The manufacturing process of the perforation is equally imprecise: functional wear marks that have obscured the manufacturing stigmatas on both the chimney and the lips. However, it should be noted that there are a few small cupules (oval shaped depression) or curved nicks (1 to $2 \mathrm{~mm}$ ) still slightly visible on the periphery of the perforation (fig. 3-3 and 3-4). These and some irregularity in the perforation appear to be consistent with the use of bifacial «picketing» (piquetage) to dig a circular depression by progressive material removal; the depression, drawing the future chimney, can then be enlarged and regularized by semi-rotary drilling as commonly observed on other objects of this type (Goutas 2004). 


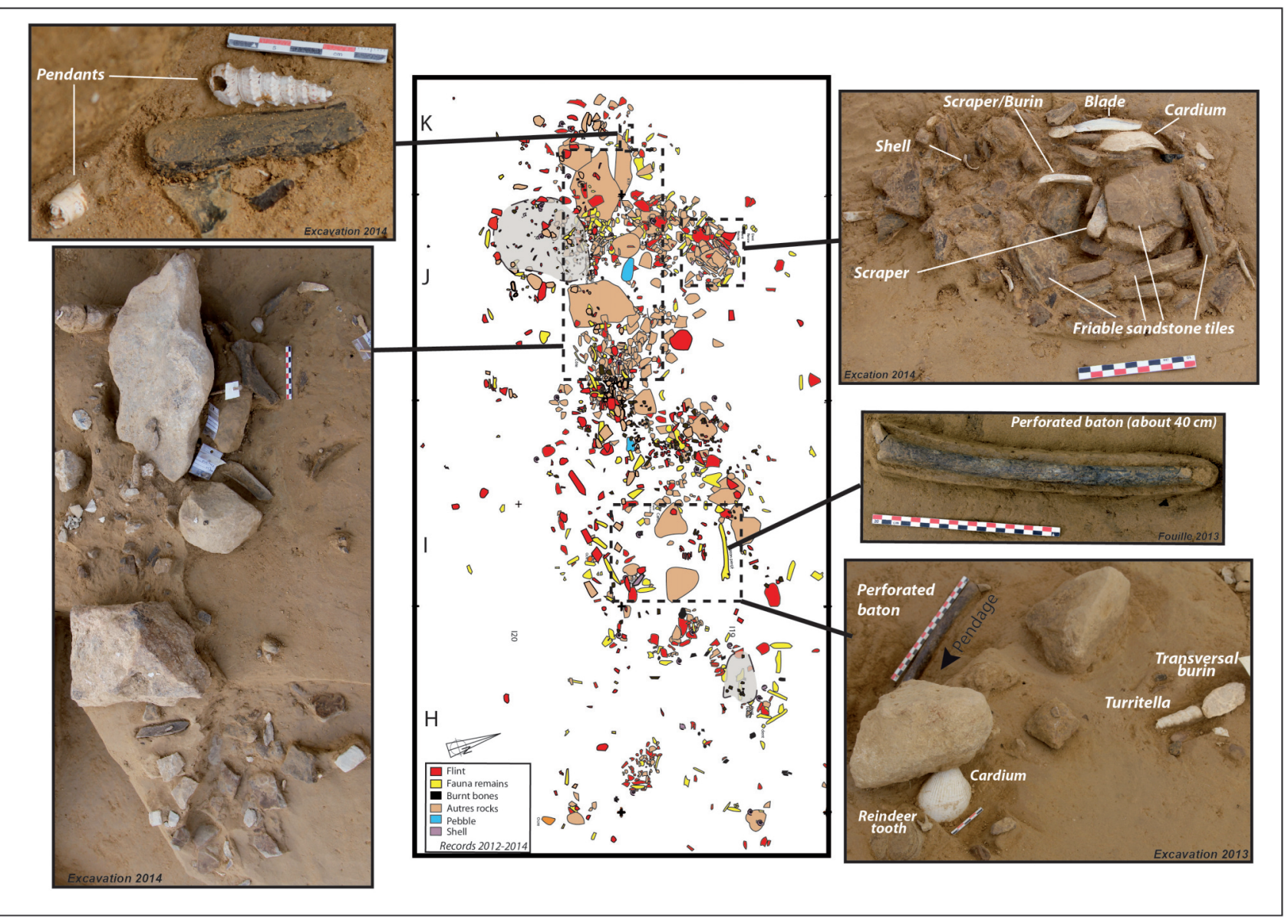

- FIGURE 4 -

« Le Colombier », Chézy-sur-Marne (Aisne, France). Location of the perforated baton within the pit-like structure (photo and Computer graphics C. Montoya).
"Le Colombier », Chézy-sur-Marne (Aisne, France). Localisation du bâton percé au sein de la structure fossoyée (clichés et infographie C. Montoya).

\subsection{3 | Macro use-wear}

Different types of macro-tracks - fracture and surface alteration - were found on the part.

The fracture: only the one affecting the perforation is of functional origin. It is oblique to the axis of the beam and occurred on fresh antler; its amplitude is very important, since three quarters of the perforation are now missing. The violence of the fracture is observed in particular in the extent $(36 \mathrm{~mm}$ long) of the tongue-shaped tearing present on the posterior surface of the beam. According to the typology established by A. Rigaud (2001), this distal fracture is of subtype b2 (fig. 3-5 and 3-6). A careful check of the faunal remains will be necessary to ensure that the complementary fragment(s) of the perforation are not present. It is questionable whether the fracturing of the tool took place on the site; according to this hypothesis, the missing fragments would still have to be discovered or identified. Their absence on the site is also possible insofar as the perforation bears stigmatas suggesting that the tool should be recycled after fracture (see below).

surface alterations: these correspond to crushing and blunting of the perforation wall.

Two main types of crashes were observed. They correspond to very distinct phases of use of the tool.
- The former can be related to the primary function of a perforated baton and are located inside the perforation and on its periphery. The compression of the fibres indicates the passage of a "foreign body» inside the perforation. The inner and outer walls of the perforation have asymmetrical crushing forming two converging opposite planes: one, with a grazing incidence (inclination less than $10^{\circ}$ ), extends over the inside of the beam and extends over a length of $7 \mathrm{~mm}$; the other, forming a more or less horizontal wear plane, is limited to the chimney and the external wall of the perforation. Crushing results from progressive and repeated contact with a foreign body (compression and/or friction), with a relatively soft or semi-hard material, or in any case of a hardness lower than that of a reindeer antler. The location of the crushing indicates that the foreign body acted along a transverse or oblique axis within the perforation from the internouter surfaces of the boom (fig. 3-7). Considering the asymmetry of visible crushes, it is questionable whether they were formed simultaneously in opposite bifacial symmetry (symétrie bifaciale opposée) subsequently to the transverse passage of a foreign body, or whether they result from the oblique passage of a body that has generated the formation of wear in alternating symmetry (symétrie alterne). Finally, the presence of an «overstepping» fracture on the posterior side of the beam (left 


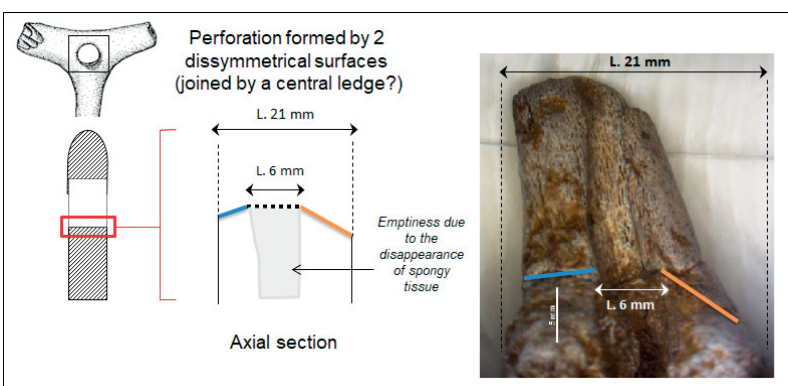

edge of the tool) also indicates that a «lateral» mechanical stress was also exerted on the perforated baton; i. e. by pressure from the antero/posterior sides of the beam.

- The second types of crushing, referred to as secondary, cover the fracture plans affecting the «perforation ring»; so they were created after it (fig. 6-1 and 6-2). On the fracture surfaces located on the posterior side of the beam, the bone fibres are compacted and relatively flat on one edge of the perforation (fig. 6-3) and, thus, form a small convex bead on the other edge (fig. 6-4). On the anterior side of the beam (right edge of the tool), the obliqueness of the fracture plane forms a bevel on which the bone fibres are also compacted unidirectionally, towards the outside of the perforation (fig. 6-5 and 6-6). These crashes show that the pierced stick has been recycled; unlike the previous one, this second use did not induce a continuous or sudden traction on the perforation but testifies to a laid down gesture (made likely by friction).

Near an old glued fracture, there is a short zone of parallel and oblique striations, barely visible, located on the outer side of the beam, a few mms from the perforation (fig.7, $n^{\circ} 7$ ). This type of stigmata, generally observed on the walls of the perforation in association with crushing, has been interpreted as the result of an "action laid down, performed by an external material intended to contain abrasive elements, such as silica» wich would characterize «the etching bite of the material flowing (...) into the perforation»-. This material could be similar to a rope (Lompré 2003: 35).

In fact, among the best documented functional hypotheses at present, those considering pierced sticks as tools involved in lever or traction systems (Rigaud 2001; Lompré 2003) could be adapted to the first observations made on Chézy's perforated stick. The experimental data available so far concern pieces discovered in the Magdalenian context; on these pierced sticks, the stigmatas, in particular the crasches, are organized in alternating symmetry on and around the perforation. However, other studies on older contexts (Gravettian) reveal greater variability in the arrangement and structuring of use-wear within the perforation (Goutas 2004).

\section{2 | A block in the process of debitage? (WSC 2014 - n 7322 - D20 "matrice" [parent entler)]}

\subsection{1 | Morphometry and typo-technological affiliation}

The first piece, No. 7322, is a left antler from a killed reindeer found in square D20. The anatomical portion preserved corresponds to the base + beam A + bez tine

\section{FIGURE 5}

« Le Colombier », Chézy-sur-Marne (Aisne, France). Crushes observed on the perforation ring and chimney topography (photo and computer graphics $\mathrm{N}$. Goutas).

"Le Colombier », Chézy-sur-Marne (Aisne, France). Ecrasements observés sur l'anneau de la perforation et topographie de la cheminée (cliché et infographie N. Goutas).

(fig. 7-1 and 7-2). According to the reference measurements taken by K. Gripp in 1935 on fossil branches of known age and sex from the Meiendorf site in Germany and according to the circumference of its beam $(110 \mathrm{~mm})$, the Chézy reindeer antler can come from an adult animal, either female (even aged) or male of 4 years and older. Indeed, its circumference is too large to refer to that of a young female or a subadult male antler (Table 1). Taking into account other criteria helps to refine our determination.

The full development of the antler, the significant size of its bez tine and the thickness of the compact tissue $(5 \mathrm{~mm})$ measured at the top of the beam A allow to integrate it into the medium/large-size class, and possibly to attribute it to a young adult male (Averbouh 2000). The kept bez tine is about $105 \mathrm{~mm}$ long; the rest of the mesial part and its distal end are missing. The first tine is absent; it is, in fact, frequent that this andouiller does not develop and materializes by a simple tuberosity at its base, which would be the case here.

Since it is a massacre reindeer antler, one can wonder if its acquisition can be linked to the reindeer hunted during the occupation of the site? Indeed, according to archaeozoological studies conducted by O. Bignon (Montoya et al. 2012, 2014; 2019), the remains of about nineteen individuals (NMIC) have been found in the LGM levels of Chézy, making reindeer the majority game. The hunting practiced in Chézy is called attritional insofar as it shows a preferential orientation towards young and old adults. The 3-6 year old class to which the massacre antler would relate «is significantly under-represented». According to the skeletal profiles, the skull boxes were also removed to the site. Antler no. 7322 could therefore have been brought at the end of a local hunting episode.

In terms of typology and technology, artifact CSM-7322-D20 appears to correspond to an abandoned block in the process of debitage. Its comparison with the category of "extraction matrices» is also plausible, although not certified. The antler, when discovered (fig.7-1 and 7-3), had a long, straight and narrow depression along beam A (anatomical anterior side) -stigma 1- which suggested a shallow grooving groove. In parallel, another depression stigma 2- of a somewhat different nature, of very limited length, and this time perpendicular to the first (fig. $1, n^{\circ} .3$ ) had also been noticed. The observation of these stigmatas was difficult due to the poor surface condition of the antler. In addition, once out of the ground, a portion of the beam severely weakened by cracks, broke into 15 fragments 57 to $15 \mathrm{~mm}$ long (fig. 7-4). 


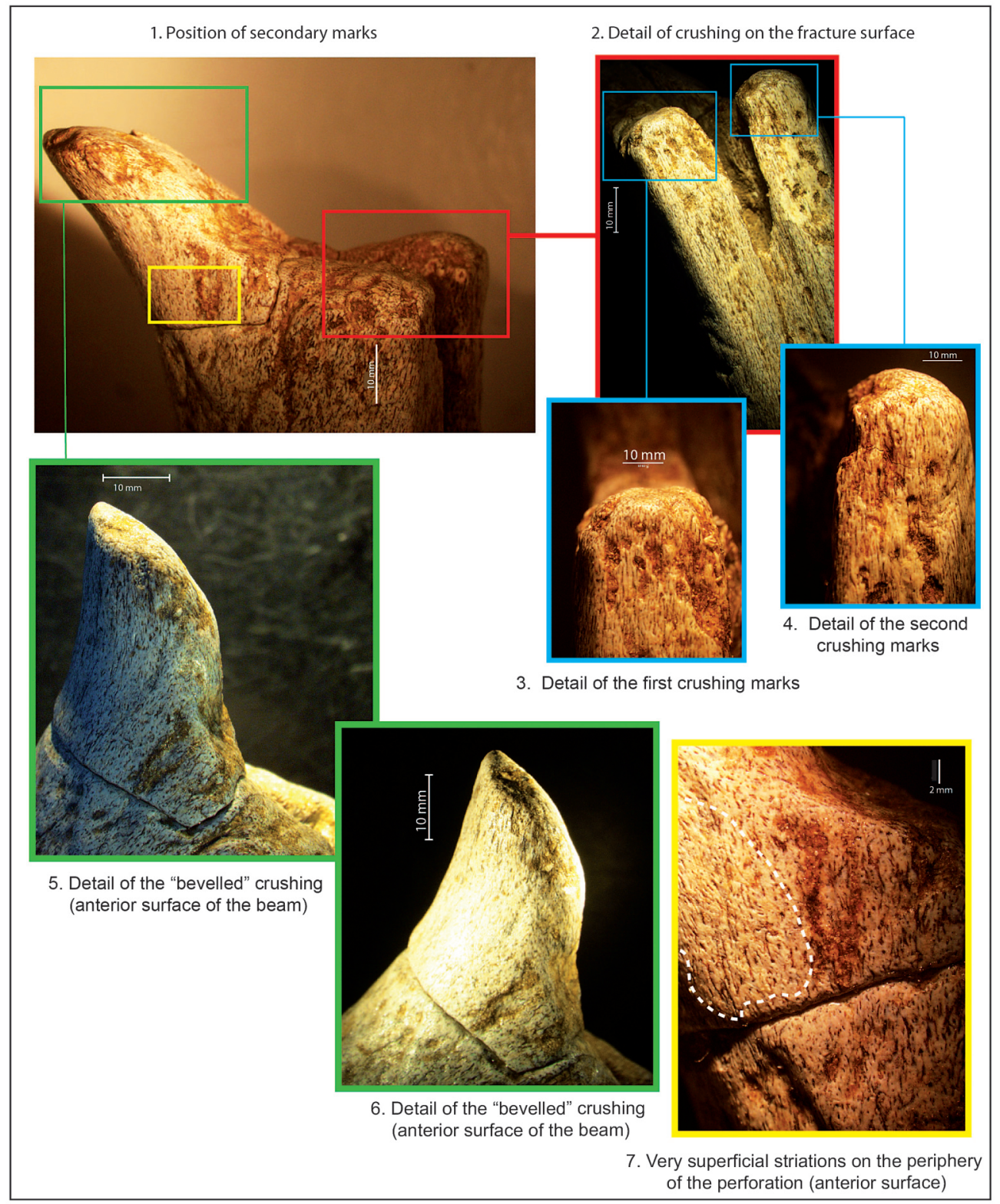

\section{FIGURE 6}

" The Colombier », Chézy-surMarne (Aisne, France). Secondary crushing located on the fracture planes of the perforation and a zone of superficial striations on the periphery of the perforation (photos and computer N. Goutas).

"Le Colombier», Chézy-sur-Marne (Aisne, France). Ecrasements secondaires localisés sur les pans de fracture de la perforation et plage de stries superficielles en périphérie de la perforation (clichés et infographie N. Goutas).

\subsection{2 | Technical stigmatas}

After observation under a stereoscopic microscope, the technical status of stigma 2 remains doubtful. It could be the remains of a gorge resulting from a shallow removal by direct percussion (fig. $1, n^{\circ} 5$ C-D). More precisely, it could be a short portion of one of the gorge walls. Its microtopography, stairs-like, evokes the controlled and continuous removal of material chips (removal scars). The precise length of this «depression» is no longer determinable, the beam is now broken at this point. However, according to the pictures of the antler before it was taken out of the ground, it was 20 to $30 \mathrm{~mm}$ long. Now, only $10 \mathrm{~mm}$ of its original length is still really observable. Further on, towards the base of the antler, small isolated and undoubtedly anthropogenic notches were also observed (fig. 7-5 E-F).

This possible sectioning gorge is in direct association with stigma 1, a longitudinal grooving groove (fig. 8-1). Again, the multiple fractures of the beam allow us to observe one side of the groove, not the groove in full section. The preserved area is visible unevenly and discontinuously over a length of nearly $110 \mathrm{~mm}$. The best preserved portion of the groove plane is about $35 \mathrm{~mm}$ long (fig. 8-2). It has microstriations parallel to each other and slightly oblique (fig. 8-2 and 8-4) resulting from contact with a flint tool used according to a radial plane (fig. 8-5). The fineness of the groove indicates the use of a very fine burin tool; the very narrow grooving seems to have reached the spongy bone tissue in some places. The difficulty in reading the groove is due to the surface alterations of the compact bone tissue and the deformations of the beam after its restoration. Indeed, the sediment contained in the perch ensured its maintenance. Once removed, the cracks running through the antler widened and opened the beam in several places. However, one of these cracks will have been initiated within the grooving groove itself, the latter offering a zone of fragility in the material. Unlike fracture sections resulting from a natural cracking process, which clearly show a tearing of the bone fibres, the "open surfaces» that we refer to a vestigial grooving groove section crossed by a crack are regular and blunt, and in places, the bottom of the groove is still visible (fig. 9-1 and 9-3). 


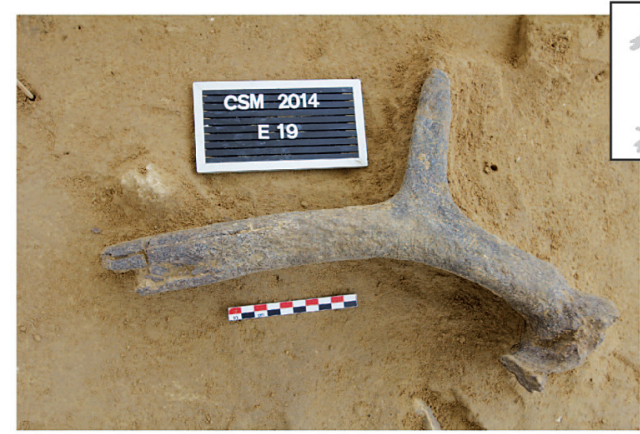

1. Antler at the time of discovery

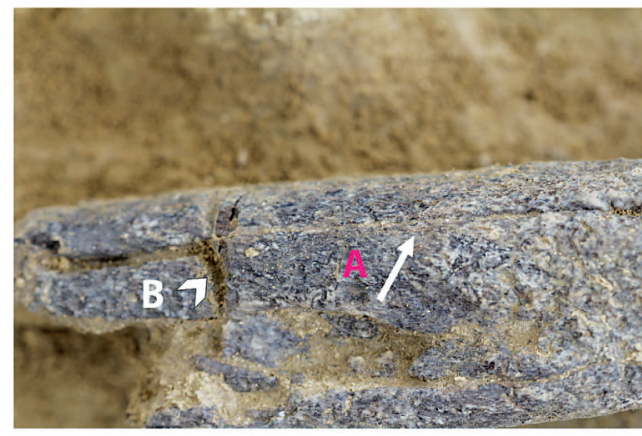

3. Detail of the pits observed on the beam, before restoration

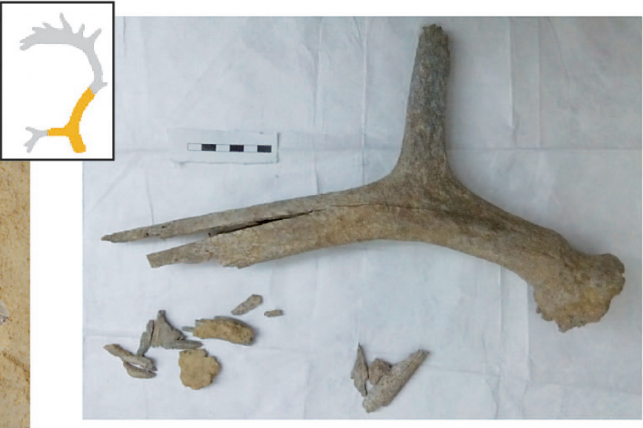

2. Antler after being removed and restored

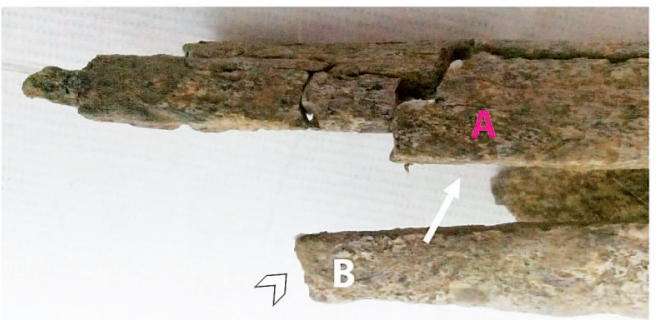

4. Same pits but this time after restoration of the antler (note the opening of the longitudinal pit)

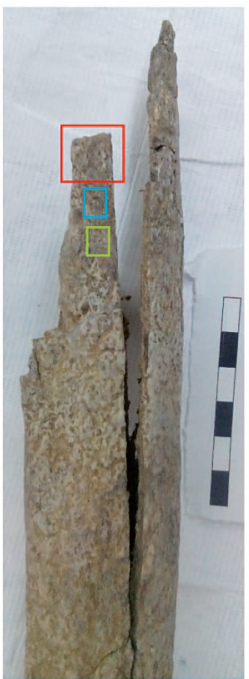

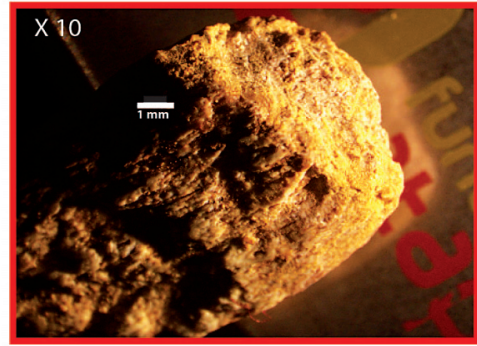

C

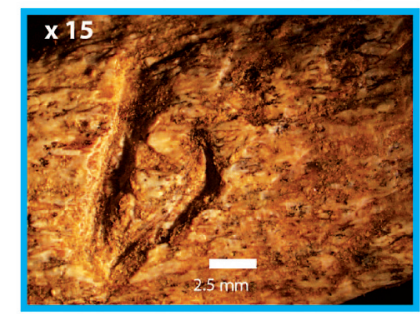

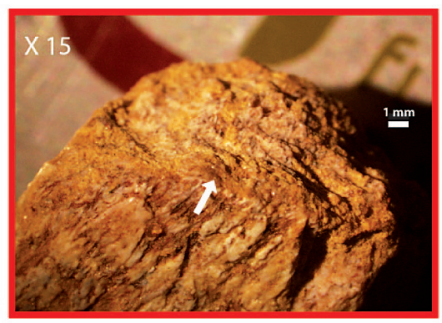

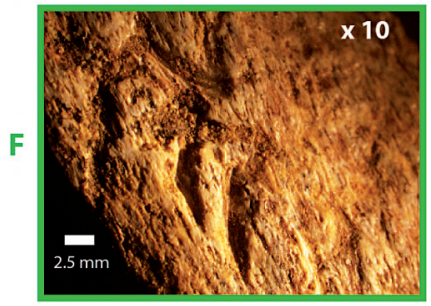

5. Detailed views of the possible sectioning surface by gashing $(C$ and $D)$ and isolated gashes $(E, F)$

\section{FIGURE 7}

« Le Colombier », Chézy-sur-Marne (Aisne, France). Block in the process of debitage on reindeer antle (artifact $n^{\circ}$ 7322): general views in situ (nos 1 and 3 ) and detailed views of a possible notching plane, after restoration ( $n^{\circ} 2,4$ and 5$)$ (photos N. Goutas).

"Le Colombier », Chézy-sur-Marne (Aisne, France). Bloc en cours de débitage sur bois de renne (pièce no 7322): vues générales de la pièce avant prélèvement (nos 1 et 3 ) et vues de détails d'un possible pan d'entaillage, après restauration (nos 2, 4 et 5) (clichés N. Goutas).

\begin{tabular}{|l|c|c|c|c|c|c|}
\hline \multicolumn{1}{|c|}{ Âge } & $\begin{array}{c}\text { A ans et } 8 \\
\text { mois }\end{array}$ & 10 ans & 20 ans & 2 ans & 3 ans & 4 ans \\
\hline $\begin{array}{l}\text { Longueur de } \\
\text { la circonférence } \\
\text { (en mm) }\end{array}$ & 75 à 90 & 135 à 140 & 115 à 125 & 50 à 77 & 80 environ & 100 à 110 \\
\hline $\begin{array}{l}\text { Longueur de la } \\
\text { perche (en mm) }\end{array}$ & 340 à 540 & 700 & 700 & 530 à 560 & 570 & 930 \\
\hline
\end{tabular}

\section{- TABLE 1 -}

Dimensions of fossil reindeer antlers of known age and sex from the Meiendorf site in Germany (after Bouchud 1959 in Goutas 2003).
Dimensions des bois de rennes fossiles d'âge et de sexe connus du site de Meiendorfen Allemagne (d'après Bouchud 1959 in Goutas, 2003). 


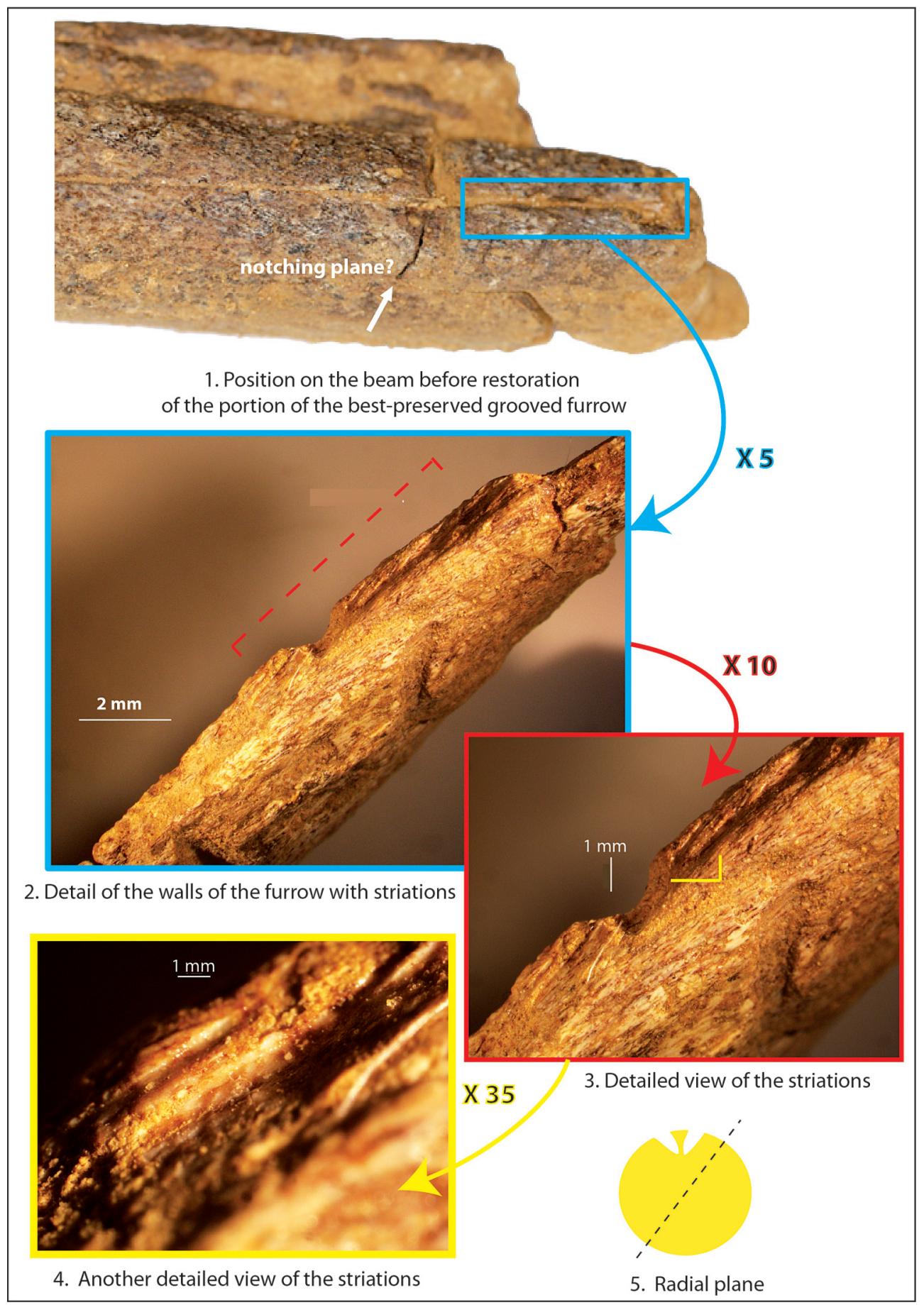

\section{FIGURE 8}

« Le Colombier », Chézy-sur-Marne (Aisne, France). Block in the process of debitage on reindeer antler (artifact $n^{\circ} 7322$ ): detailed views after restoration of the grooving groove (photos N. Goutas).

"Le Colombier», Chézy-sur-Marne (Aisne, France). Bloc en cours de débitage de Chézy sur bois de renne (pièce $n^{\circ}$ 7322) : vues de détails après restauration du pan de sillon de rainurage (clichés N. Goutas).

The interpretation of this groove is delicate, given its very residual nature; it could correspond to a tracing (fig.9-4), the first step in the formalization of a grooving groove (" sillon de rainurage ») (Dauvois 1974). If the action of grooving stricto sensu does not require the mastery of complex skills, it does require the skill and safety of the hand (op. cit.). The initiation of grooving is therefore an important step because it is the one that must guide the flint tool during the first passages in order to prevent it from slipping and leaving its path, which would lead to the formation of a discontinuous groove. The initiation of grooving can easily be done with a small angle burin, or with the dihedral or trihedral with a small flake (Averbouh 2000). Once the steering groove has been created, the burin no longer slips, and the actual grooving can begin.
The groove can then be widened in such a way as to obtain, technically, a real groove (with two sides and a flat bottom). However, this was not the case on this waste since the grooving was stopped very early on. The reasons for this discontinuation remain undetermined. The chronological arrangement of the longitudinal grooving and the possible notching can no longer be reconstructed with certainty. It can only be assumed that the latter was later than the grooving. It is possible that the realization of this shallow groove is linked to the detachment of rods located higher on the branch, on the internal side (in anatomical position) of the beam B/C (fig. 9-5). This hypothesis would allow for a better understanding of a technical detail. First, the portion of the grooving panel that is best preserved is directly associated with the 


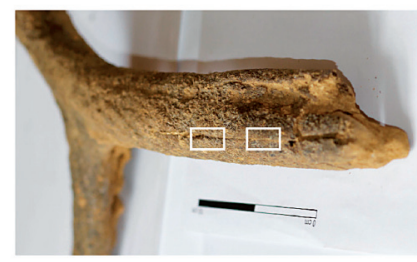

1. Grooving surface before restoration of the antler and widening of the crack

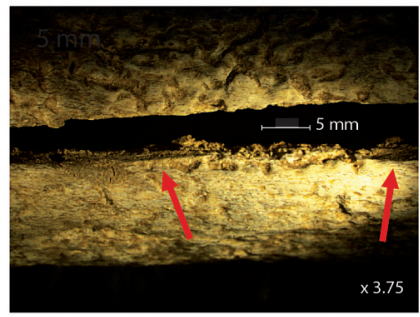

2. Detail of the grooving surface after restoration
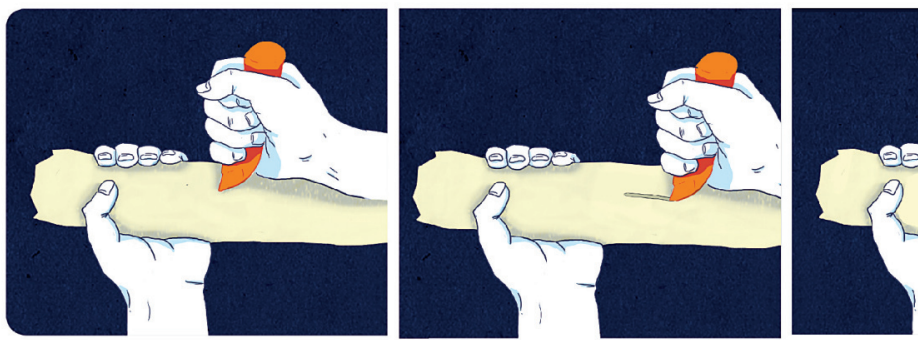

4. First grooving stage, "tracing" (drawing A. Verdon)

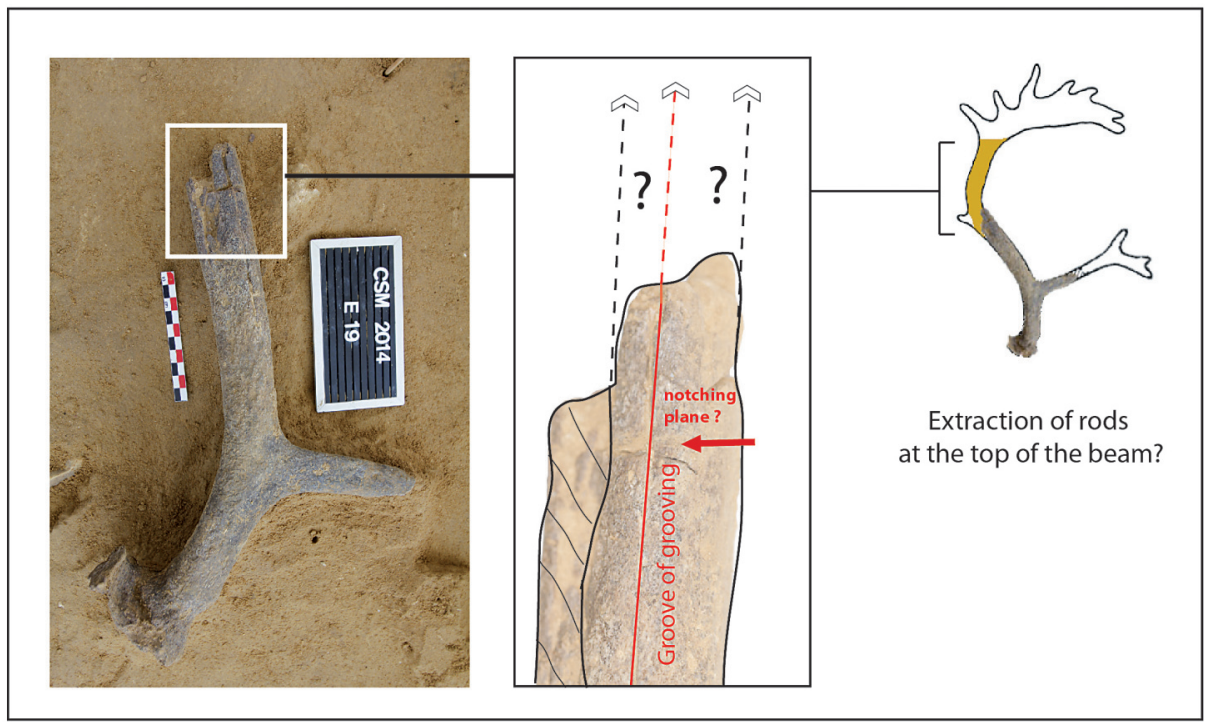

5. Location of the hypothetical extractions of rods on the beam

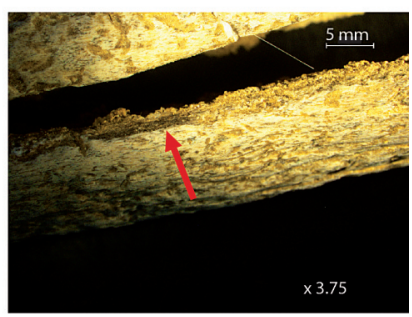

3. Another detailed view of the grooving surface

\section{FIGURE 9}

« Le Colombier », Chézy-sur-Marne (Aisne, France). Block in the process of debitage on reindeer antler (artifact $n^{\circ}$ 7322): detailed views after restoration of the groove and location of possible extractions carried out on the beam (photos and computer graphics N. Goutas).

"Le Colombier », Chézy-sur-Marne (Aisne, France). Bloc en cours de débitage de Chézy sur bois de renne (pièce $n^{\circ}$ 7322) : vues de détails après restauration du pan de sillon de rainurage et localisation des hypothétiques extractions sur la perche (clichés et infographie N. Goutas).

possible transverse cutting groove (see fig. 8-1). Then, the obliquity of the microstriations on this grooving section indicates a relaxation of the pressure exerted on the flint tool (fig. 8-2 and 8-3), which generally occurs at the end of the procedure. In any case, the purpose of these various technical actions (notching? and grooving) remains very speculative for the moment.

\section{3 | A possible extraction matrice (CSM2012-n² $2710-$ GH2O)}

\subsection{1 | Morphometry and typo-technological affiliation}

This piece (fig. 10-1 to 10-3) consists of the basilar + pole A portion of a left reindeer slaughter antler (presence of part of the skull and pedicle) probably belonging to an adult male given the first measurements taken. Indeed, the total length of the piece is about $300 \mathrm{~mm}$ : pole A (first part of the pole) is present on its first third and its width taken above the first tine and then at the base of the bez tine are respectively $50 \mathrm{~mm}$ and almost $40 \mathrm{~mm}$. In addition, the gap between these two tines is wide, which is more characteristic of a male than a female reindeer antler (see Averbouh 2000 reference collection, Averbouh 2015).

The poor state of conservation makes it difficult to read. It seems, however, that a line of necrosis is emerging between the pedicle and the medallion, which would indicate the next shedding of the antler. If this first observation is true, it would mean that it was obtained in late fall. But it will be difficult to determine whether the work carried out on this antler closely followed its acquisition: it is no longer possible to read the traces of deterioration that animals or plants could have left on the raw antler and would indicate that it remained more or less long in the open air before its debit.

\subsection{2 | Technological elements}

Several observations can be made at a first observation: the presence of a wide empty band on the inner surface of the beam (fig. $9, n^{\circ} 1-A$ ), the absence of a first tine 


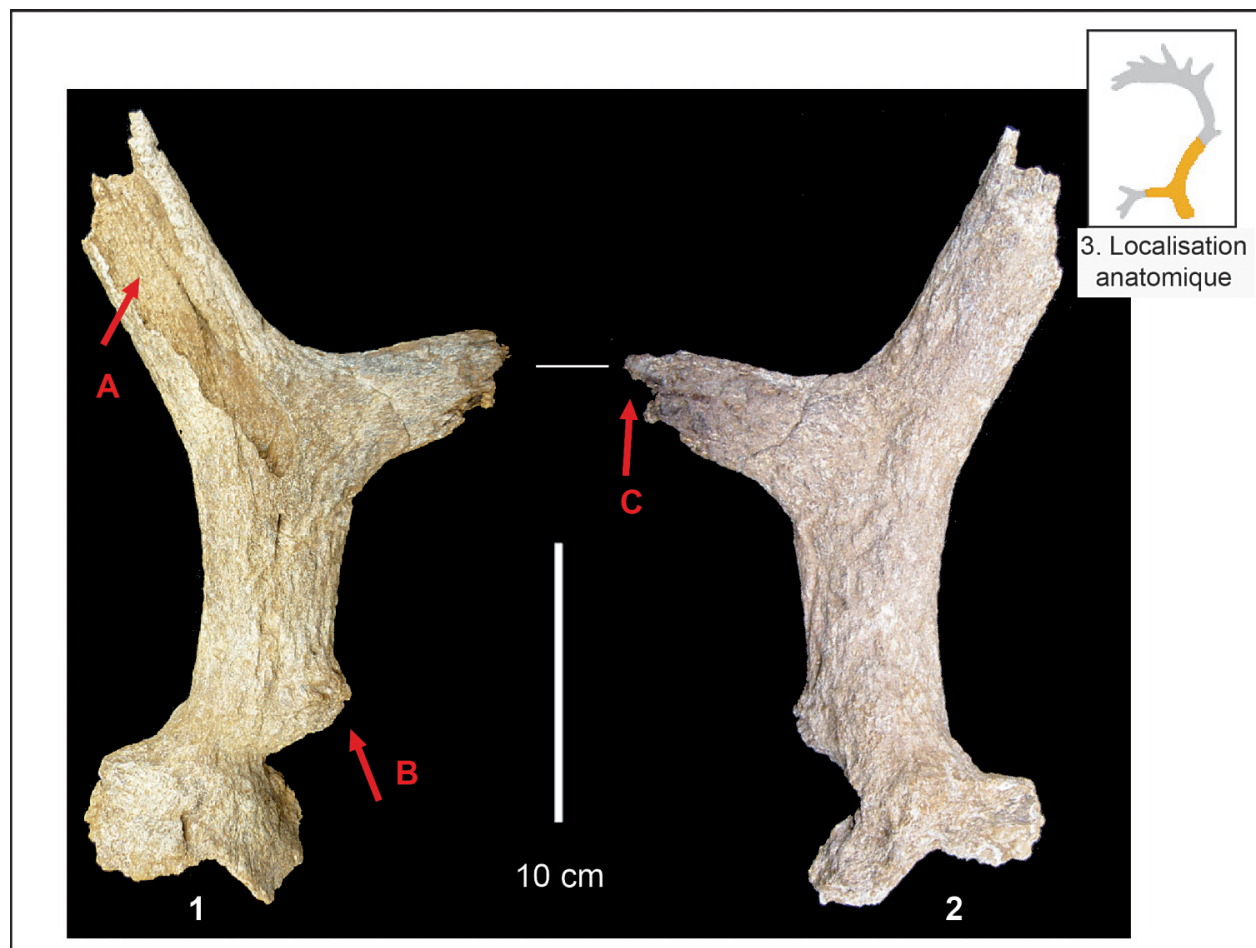

1 and 2. Overall views

(on the left, internal surface of the beam; on the right: external surface)
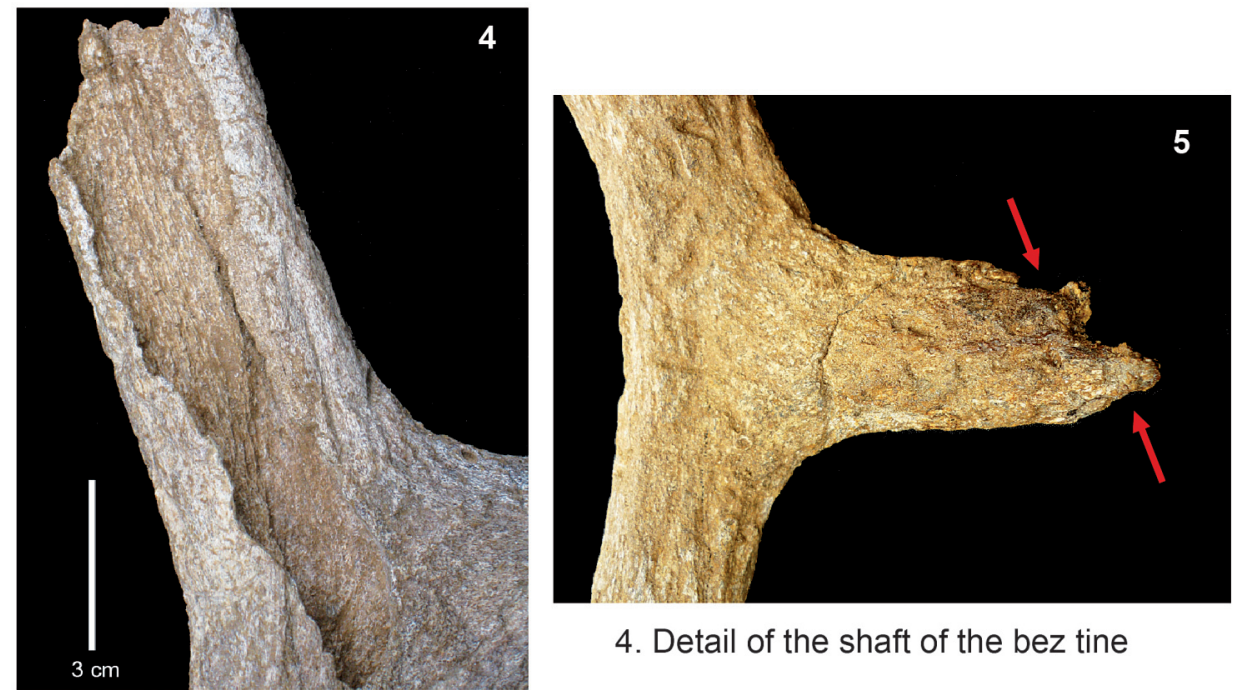

4. Detail of the shaft of the bez tine

\section{FIGURE 10}

« Le Colombier », Chézy-sur-Marne (Aisne, France). The possible reindeer antler extraction matrice (photos D. Gilot)

" Le Colombier », Chézy-sur-Marne (Aisne, France). La possible matrice d'extraction en bois de renne (clichés D. Gilot)

\section{Detail of the possible remains} of the imprint of rod extraction

eliminated at its base and the presence of the first third of the bez tine (fig. 9, $\mathbf{n}^{\circ}$ 1-B and C). This set of features is commonly observed on a single rod extraction « matrice ».

The empty strip can, in fact, refer to the extraction of a support of the strip type, generally wide and roughly rectangular. This rod, if extracted, could have a minimum length (due to breakage) of $140 \mathrm{~mm}$, a maximum width of between 35 and $40 \mathrm{~mm}$ and a maximum thickness of $10 \mathrm{~mm}$. It would have largely consisted of compact bone tissue, which would once again argue in favour of an adult male antler. This does not solve the question that remains: has a rod been extracted or not? In fact, to delimit this future support and prepare its extraction, it is necessary to draw its outline and initiate the future fracture lines sufficiently so that the detachment of the rod follows them exactly.

In the Magdalenian, this preparation for extraction is done, at least for the longitudinal edges of the future support, with a very commonly used wear technique -groovingwhich simultaneously creates characteristic planes on the support and on the «matrice». However, only the straight edge (looking at the piece in anatomical position, fig. 10-4) evokes a groove plane by its inclination (steep/with worked surface) and by its rectangular morphology (hardly resulting from an action other than anthropogenic). However, the fine reading of the characteristic striations 
was not possible during this first examination and must be carried out under a scanning microscope before making any well-founded hypothesis, especially since the opposite edge (left) is much less well preserved and has a general appearance more reminiscent of a broken edge than a groove plane.

Similarly, the fact that the first tine is removed at its base (fig. 10-1B) suggests that this is due to an anthropogenic action, possibly a transverse sectioning action by removal by direct percussion quite common during this period. But no element, even vestigial, has so far been identified to corroborate this hypothesis. Again, a second, more detailed examination is required.

Finally, the presence of the first third of the bez tine is also a common feature observed on single rod extraction matrices. But the reading of the fracture zone is, once again, not easy and deserves to be examined at a higher magnification, in particular to verify that the «pacifier» shape (fig. 10-5) is not linked to animal action (after the waste had been abandoned).

In the end, this piece presents several criteria characteristic of a single rod extraction matrice but it remains to be demonstrated whether this hypothesis based essentially on morphological analogies is valid.

\section{4 | A fragment of a bez tine (CSM2014 - n 7117 - D20)}

A last piece of reindeer antler was discovered during the 2014 season ( $n^{\circ}$ 7117, fig. 11). Considering its dimensions (139 $\mathrm{mm}$ long, $30 \mathrm{~mm}$ wide and $18 \mathrm{~mm}$ thick), associated with its very flattened oval cross-section, its overall elongated shape and the ratio between compact and spongy bone tissue, we identify this fragment as a mesial part of a bez tine of a medium-large sized antler. At about fifty centimetres, artifact $n^{\circ} 7322$ has been abandoned. As these two pieces belong to the same class-size, we wonder about the possibility that these two anatomical elements belong to the same antler. But these two parts cannot be physically (concretely) reassembled together and this hypothesis, such as the fact that this fragment of ice andouiller belongs to the group of worked parts, cannot be confirmed.

\section{5 | The bone artifact (CSM2012): waste or tool?}

This artifact (fig. 12, fig. 13) consists of the joint portion (neck and glenoid cavity) and the beginning of the pallet of a horse scapula. The alteration of its surface, very marked by vermiculations left by the roots of plants, makes it particularly difficult to read. Two questions were asked to determine whether this part could have been used as a hammer, a hypothesis put forward by C. Montoya: one concerned the natural or anthropogenic origin of the scapula fracture from the end of the cervix in order to improve the grip of the supposed tool; the other concerned the presence of stigmatas associated with a percussion around the glenoidal cavity and on the supraglenoidal tuber.

In the current state of observations, we cannot reliably answer the first question, but we have nevertheless observed localized notches near the glenoidal cavity, on the supraglenoidal tuber, and more scattered on the surfaces of the scapula. These nicks (or notches) are short (a few millimetres at most), shallow, marked at the bottom by a double groove and they mostly have an oblique profile with a flat bottom. All these elements appear to be consistent with the action of a lithic cutting edge, and therefore with an anthropogenic action. The preliminary examination has shown that there may also be two distinct subtypes of nicks that have yet to be precisely characterized. For the time being, it is only noted that the nicks present do not correspond to the main stigmatas we see on the archaeological organic hammers used for flint knapping (cupules, V-notches, compaction, etc. cf. Averbouh and Bodu 2002). Their structuring (organized, unorganized) should be characterized by their fine mapping on the piece in order to be able to determine its origin: were they created by butchery activities or by

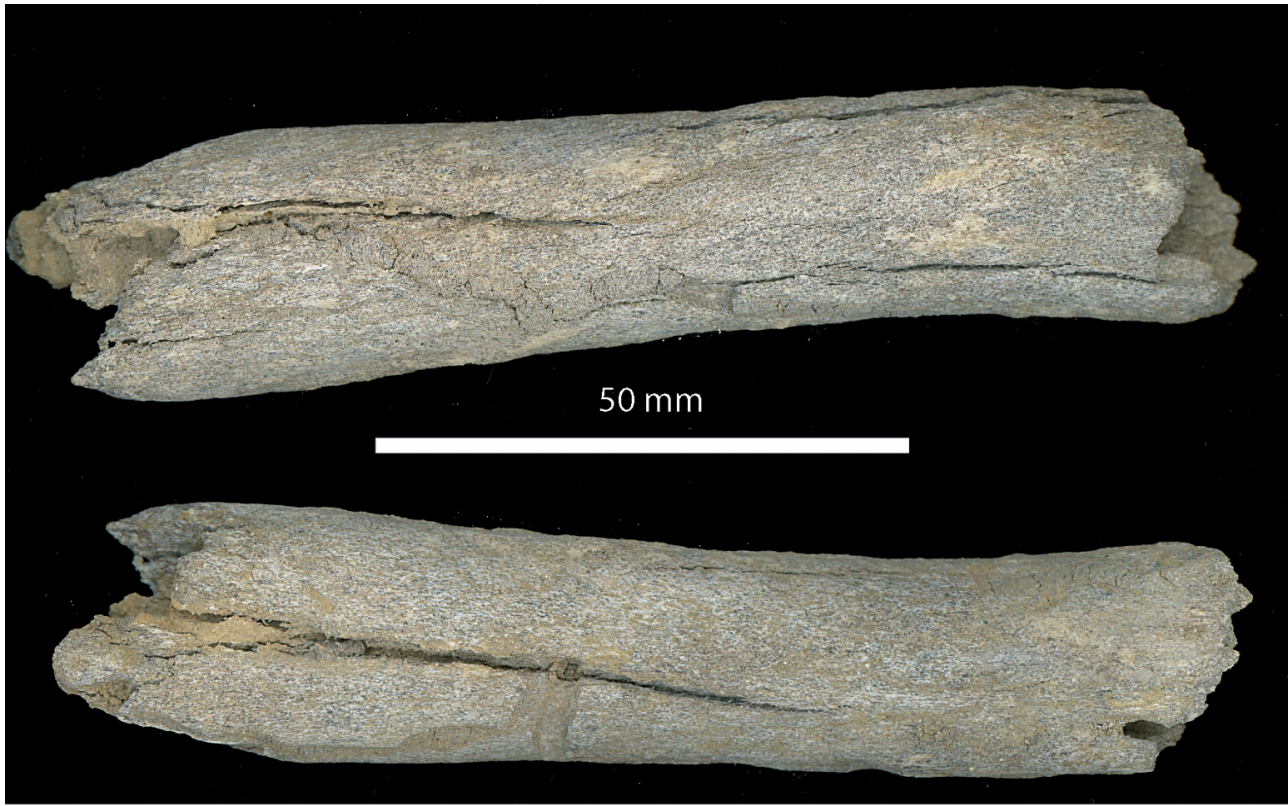

\section{FIGURE 11}

" Le Colombier », Chézy-surMarne (Aisne, France). Fragment of a bez tine, internal and external surface (photos N. Goutas).

"Le Colombier », Chézy-sur-Marne (Aisne, France). Fragment d'andouiller de glace, vues face interne et externe (clichés N. Goutas). 
processing activities? In the first case, the piece will join all the faunal remains; in the second, it will be part of the bone industry by taking the status of a tool whose use will first have to be determined if it has been active or passive.

\section{CONCLUSION : CONTEXT SETTING AND INTERPRETATION OF « LE COLOMBIER » BONE INDUSTRY AT CHÉZY-SUR-MARNE}

The Chézy-sur-Marne site undoubtedly contains elements from an osseous material industry. If among the 5 exhumed pieces, the one on bone cannot be integrated in a certain way into the series of industry out of hard animal material, this small set still presents a great coherence, if only from the raw material of the pieces and from the presence of elements, certainly sometimes tenuous but potentially attributable to a rod production by extraction by grooving.

While the use of notching is attested in Badegoulian contexts (Averbouh 2004), the use of the longitudinal grooving technique is more relevant. Indeed, the data currently available suggest that this technique was not used by Badegoulian groups to work with reindeer antlers (Averbouh, comm. SPF 2006, Averbouh and Pétillon 2011), except perhaps in the Rond du Barry whose archaeostratigraphy is unfortunately not safe (Rémy 2013). For the time being, based on data from reliable archaeological contexts, it seems that Badegoulians have exclusively produced their supports on reindeer antlers by blank production by fracturing, marking a major difference with Magdalenian groups (Averbouh comm. SPF 2006; Averbouh and Pétillon 2011; Pétillon and Averbouh 2011; Pétillon and Ducasse 2012; Averbouh 2018)

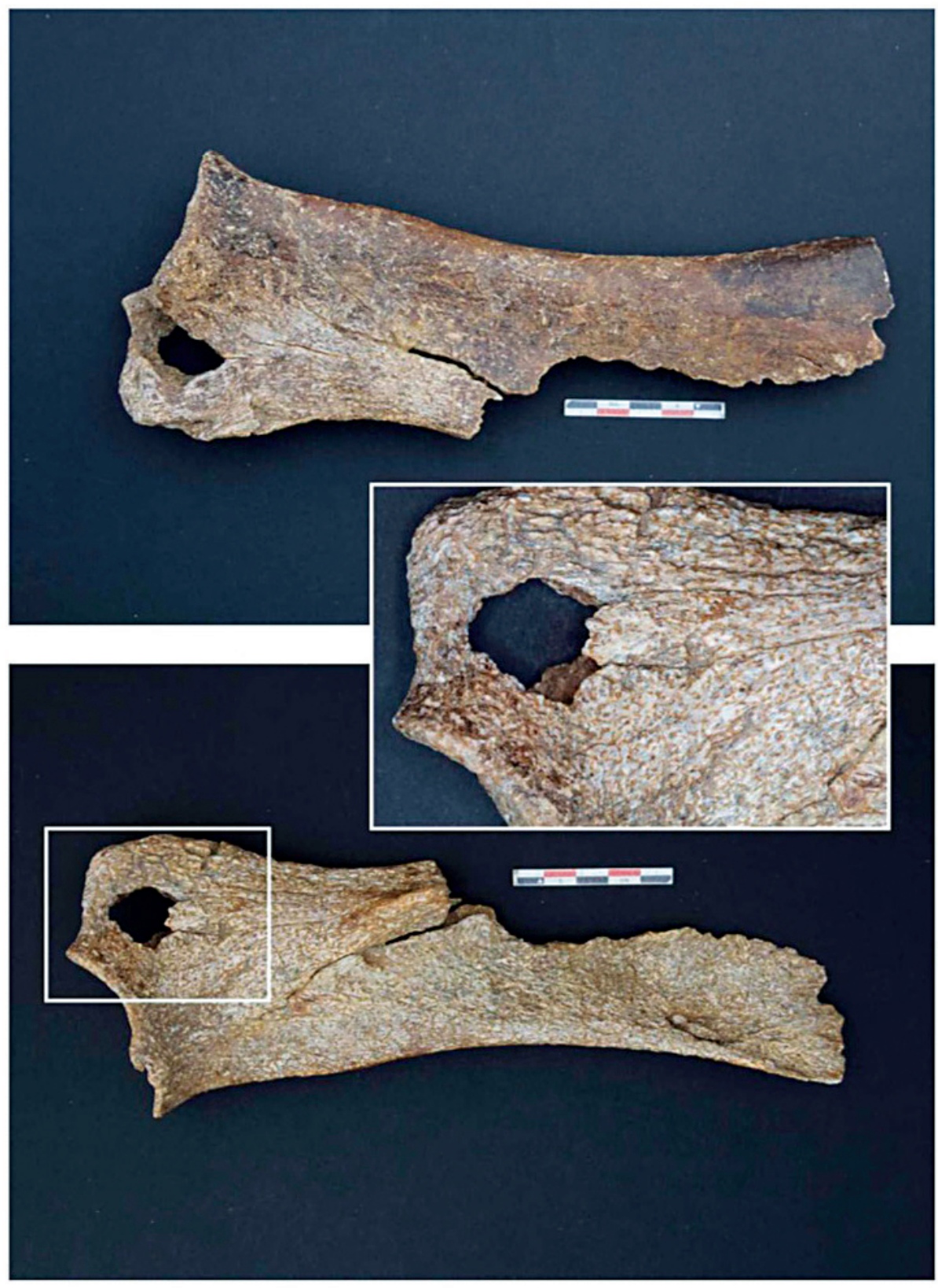

\section{FIGURE 12}

« Le Colombier », Chézy-sur-Marne (Aisne, France). The artifact on horse scapula (lateral and medial view and detailed view of the perforated area, photos C. Montoya).

"Le Colombier ", Chézy-sur-Marne (Aisne, France). La pièce sur scapula de cheval (vue latérale et médiale, Clichés C. Montoya). 


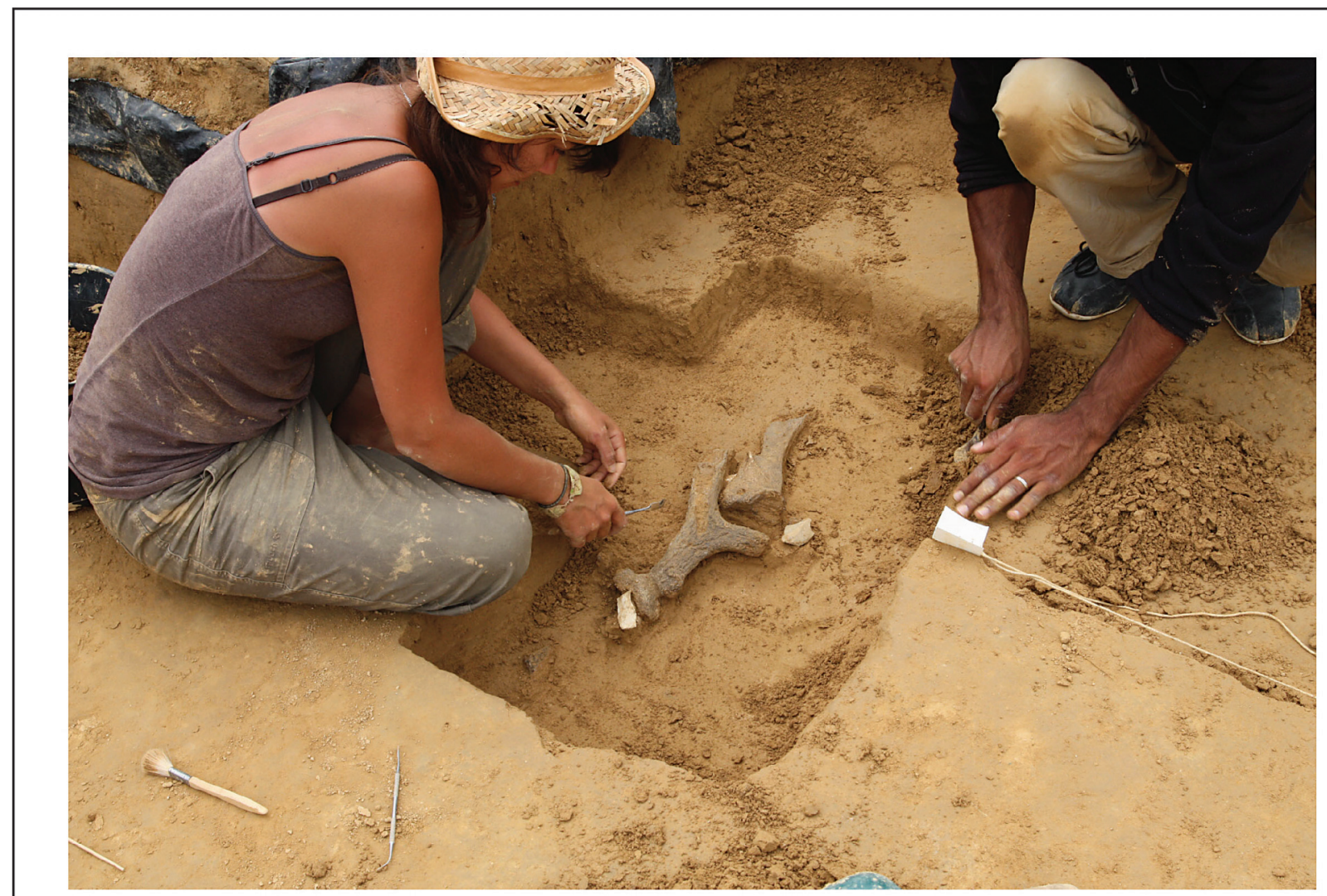

1. The two pieces at the time of discovery, overall view (Photo C. Montoya)

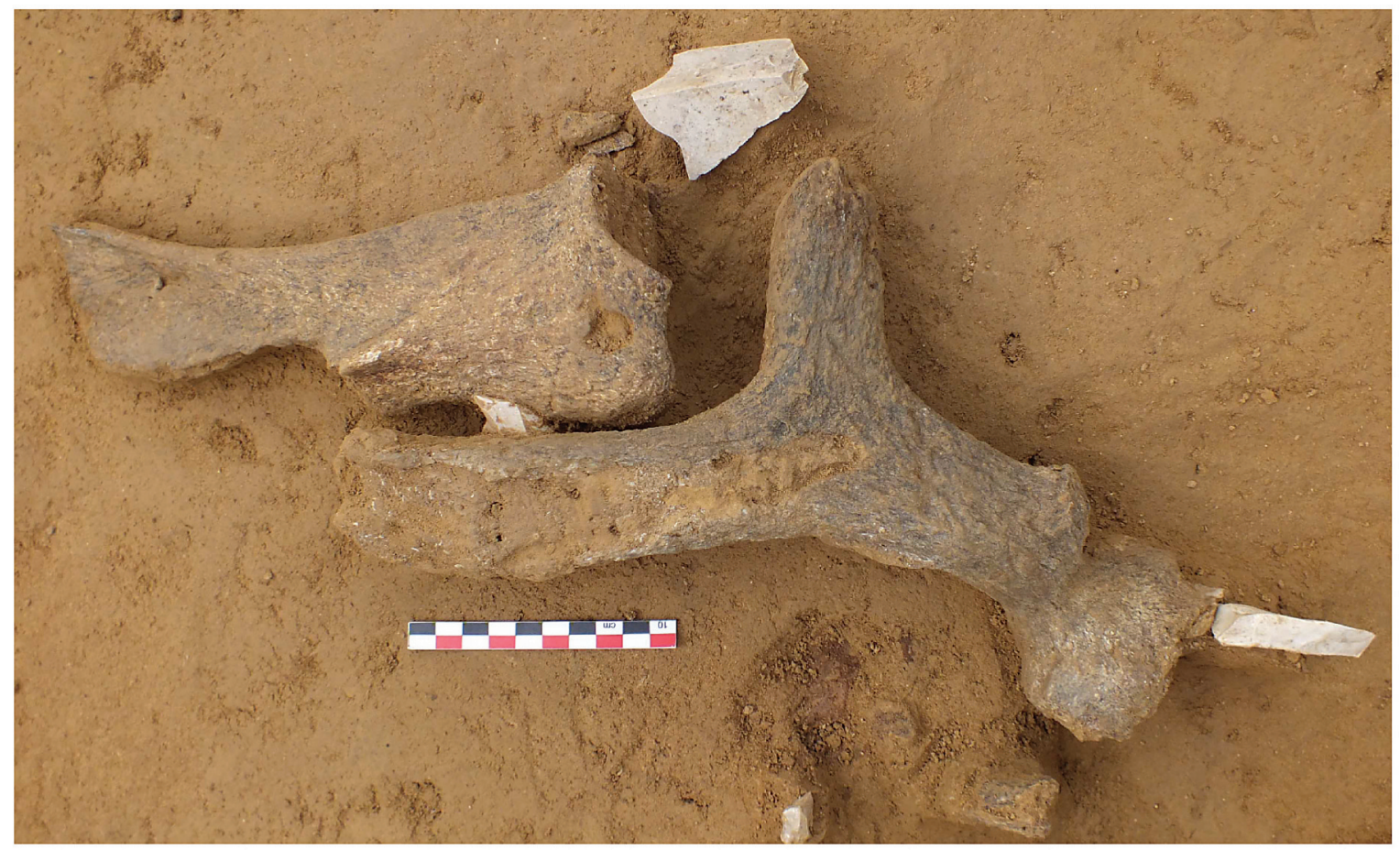

2. The two pieces at the time of discovery, close up view (Photo V. Miclon)

\section{- FIGURE 13 -}

« Le Colombier », Chézy-sur-Marne (Aisne, France). The horse scapula object and the possible reindeer antler " matrice » at the time of discovery, overall view (photo C. Montoya) and close up view (photo V. Miclon)
"Le Colombier ", Chézy-sur-Marne (Aisne, France). La pièce sur scapula de cheval et la possible matrice d'extraction en bois de renne lors de leur découverte, vue générale (cliché C. Montoya), vue détaillée (cliché V. Miclon). 
Because of their poor conservation, the matrices from « Le Colombier » at Chézy-sur-Marne are probably not the best candidates to establish that the grooving technique and more, a debitage by extraction, were used on reindeer antler in a Badegoulian context. But these are witnesses we have to take into account. Nevertheless, we insist on the importance of dissociating the punctual identification of the grooving technique, and the integration of this same technique into the «Badegoulian technical tradition»; by this we mean all the skills and know-how (sensu Pelegrin 2000) repeatedly mobilized and codified by the Chézy group in order to produce its equipment. Thus, the data currently available from the Chézy's bone material -and in particular the difficulty of reintegrating this technical observation into a global operating scheme for the blockdo not allow us to put forward the hypothesis that Chézy's human groups carried out sawing by extracting rods, using the double longitudinal grooving process, as commonly practiced by Magdalenian groups.

If this reading is confirmed and if new evidence proves it, it can then be argued that the transformation of osseous materials, and more particularly that of reindeer antler, the major raw material of this period, did not follow the same principles as those of the potentially contemporary Badegoulian groups in southwestern France.

\section{ACKNOWLEDGEMENTS}

Our thanks go to the French Ministry of Culture, DRACService régional de l'archéologie des Hauts de France (Amiens site), Conseil général de l'Aisne, ASAVA, Archaeology Unit of Château-Thierry (Sébastien Ziegler), Cédric Salot for his logistical help, Françoise Bedel and Vincent Desabeau, owners, and all the 2011-2014 diggers. Our warmest thanks also to Jean Clottes for his proofreading of the English translation and to the two reviewers for their useful advice.

\section{REFERENCES}

AVERBOUH A. 2000 - Technologie de la matière osseuse travaillée et implications palethnologiques. L'exemple des chaînes d'exploitation du bois de cervidé chez les Magdaléniens des Pyrénées. Paris: Thèse de doctorat de l'Université de Paris 1, 500 p. dactyl, 158 fig.

AVERBOUH A. 2004 - le travail des matières osseuses à Oisy Saint-Aubin in : Bodu P. et Debout G., dir. Le gisement Badegoulien du Mont-St-Aubin $2^{e}$ Rapport préliminaire de fouille programmée, campagne 2004, p. 61-64, ill.

AVERBOUH A. 2006 - Le travail des matières osseuses dans les niveaux solutréens et badegouliens du Cuzoul de Vers. Communication séance SPF Toulouse, décembre 2006.

AVERBOUH A. 2015 - Recherches autour des critères d'identification sexuelle des bois de renne, Constitution d'une collection de référence. In : Cl. Alix, Averbouh A., Karlin Cl. (Ed.), dossier : Archéologie boréale, pour le développement des recherches arctiques, Les Nouvelles de l'Archéologie, 141, p. 44-49 DOl : https://doi.org/10.4000/nda.3118
AVERBOUH A. (Ed.) 2016 - Multilingual Lexicon of Bone Industry, Version 2 (Français-Anglais-Italien-Espagnol, Allemand, Hongrois, Polonais, Russe, Bulgare, Roumain, Portugais, Danois), GDRE PREHISTOS - ARCHAEOLOGICAL STUDIES II, Hors série Préhistoire de la Méditerranée, 131 p.

AVERBOUH A. 2018 - Le travail des matières osseuses au Badegoulien ou un curieux goût pour la fracturation (The processing of osseous materials during the Badegoulian or a strong taste for fracturing). In : M. Christensen et N. Goutas (Ed.), À coups d'éclats! La fracturation des matières osseuses en Préhistoire: discussions autour d'une modalité d'exploitation en apparence simple et pourtant mal connue. Actes de la Séance de la Société préhistorique française (25 avril 2017), Paris, p. 159-164 (Mémoire 13). ISSN : 2263-3847 - ISBN : 2-913745-74-1

AVERBOUH A., BODU P. 2002 - Percuteurs sur partie basilaire de bois de cervidé. In : M. Patou-Mathis (éd.): Fiches typologiques de l'industrie osseuse préhistorique, Cahier $X$ : compresseurs, percuteurs, retouchoirs, Commission de nomenclature sur l'industrie de l'os préhistorique, Paris, Société préhistorique française, p. 117-131 (Fiches typologiques de l'industrie osseuse préhistorique, $X$ ).,

AVERBOUH A., PÉTILLON J.M. 2011 - Identification of "debitage" by fracturation on reindeer antler: case study of the Badegoulian levels at Cuzoul de Vers (Lot, France). In : J. Baron, B. Kufel-Diakowska (Ed.), Written in Bones, studies on technological and social contexts of past faunal skeletal remains. Actes du Colloque du Work Bone Research Group, Universytet Wroclawski. Wroclaw, Pologne, Instytut Archeologii, p. 41-52.

BOUCHUD J. 1959 - Essai sur le renne et la climatologie du Paléolithique moyen et supérieur. Paris: Thèse de Doctorat, Faculté des Sciences de l'université de Paris.

DAUVOIS M. 1974 - Industrie osseuse et expérimentation, In : H. Camps-Fabrer (dir.), Premier colloque international sur l'industrie de l'os dans la Préhistoire (Abbaye de Sénanque, 18-20 avril 1974), Aix-en-Provence, université de Provence, p. 73-84.

GOUTAS N. 2003 - L'exploitation des bois de cervidé dans les niveaux gravettiens de la grotte d'Isturitz (Pyrénées Atlantiques): le procédé d'extraction de baguette par double rainurage. In : P. Cattelain, $M$. Patou Mathis et D. Ramseyer (Ed.), L'industrie osseuse pré- et protohistorique en Europe. Approches technologiques et fonctionnelles. Actes du colloque 1.6, XIVème congrès de l'U.I.S.P.P. (28 septembre 2001), Liège, p. 19-28 (Bulletin du cercle archéologique, Helpay Condroz, T.26).

GOUTAS N. 2004 - Caractérisation et évolution du Gravettien en France par l'approche techno-économique des industries en matières dures animales (étude de six gisements du sud-ouest). Paris: Thèse de doctorat de l'Université de Paris 1-Panthéon Sorbonne, 680 p.

LOMPRÉ A. 2003 - Une nouvelle approche techno-fonctionnelle appliquée à un ensemble magdalénien de bâtons percés. In : A. Averbouh et $M$. Christensen (éd.) Transformation et utilisation préhistoriques des matières osseuses. L'utilisation et la fonction des objets produits, Préhistoire Anthropologie Méditerranéenne, 12, p. 147-163. 
MONTOYA C., AVERBOUH A., BIGNON O., DUMARÇAY G., GOUTAS N., PESCHAUX C., RASSAT S. 2012 - Fouille programmée de Chézy-sur-Marne (02) «le Colombier». Autorisation de fouille triannuelle 2012-2014. Code Patriarche 10437. Rapport de fouille, service régional d'archéologie de Picardie, Amiens, 83 p.

MONTOYA C., AVERBOUH A., BIGNON-LAU O., DUMARÇAY G., GOUTAS N., PASQUINI A., PESCHAUX C., RASSAT S. 2019 - Le «Colombier » à Chezy-sur-Marne (Aisne, France) : analyses préliminaires d'un site inédit du Dernier Maximum Glaciaire. In : C. Montoya, J.-P. Fagnart et Locht J.-L. (Ed.), Préhistoire de l'Europe du Nord-Ouest: mobilités, climats et entités culturelles, session 2 (Palethnologie du Paléolithique supérieur ancien : où en sommes-nous ?). Actes du XXVIIle Congrès Préhistorique de France (Amiens, 30 mai-4 juin 2016), Supplément du Bulletin de la Société Préhistorique Française, p. 141-163 (Les Mémoires de la SPF).

MONTOYA C., AVERBOUH A., BIGNON-LAU O., DUMARÇAY G., FERUGLIO V., GOUTAS N., PASQUINI A., MÜLLER K., PESCHAUX C., RASSAT S., VAN ELSLANDE E. 2014 - Fouille programmée de Chézy-sur-Marne (02). Rapport de fouille de synthèse, service régional d'archéologie de Picardie, Amiens, 207 p.

PARIS C., MONTOYA C., DERBOIS M., BIGNON O. 2011 - Chézy sur Marne, « Le Colombier », rapport de diagnostic archéologique INRAP, Service Régional de l'Archéologie, Amiens, 78 p.

PELEGRIN J. 2000 - Les techniques de débitage laminaire au Tardiglaciaire : critères de diagnose et quelques réflexions. In : B. Valentin, P. Bodu et M. Christensen (Ed.), l'Europe centrale et septentrionale au Tardiglaciaire. Actes de la table ronde internationale de Nemours (13-16 mai 1997), Nemours, APRAIF, p. 73-86 (Mémoires du musée de Préhistoire d'île-de-France, 7).

PELTIER A. 1992 - Bâtons percés. In : H. Camps-Fabrer (éd.), Cahier V: Batons percés, baguettes. Fiches typologiques de l'industrie osseuse préhistorique (5). Commission de nomenclature sur l'industrie de l'os préhistorique. Treignes: C.E.D.A.R.C., p. 7-70.
PÉTILLON J.-M., AVERBOUh A. 2012 - Le travail du bois de renne dans les couches badegouliennes. In : J. Clottes, J.-P. Giraud et P. Chalard (Ed.), Solutréen et Badegoulien au Cuzoul de Vers: Des chasseurs de rennes en Quercy. Liège: ERAUL 131, p. 359 à 386

PÉTILLON J.-M. et DUCASSE S. 2012 - From flakes to grooves: a technical shift in antlerworking during the last glacial maximum in southwest France. Journal of Human Evolution, 62(4), p. 435-465.

RÉMY D. 2013 - Caracterisation techno-économique d'industries en bois de cervidés du Badegoulien et du Magdalénien : le cas du Rond-du-Barry (Haute-Loire) et de Rochereil (Dordogne). Montpellier : Mémoire de doctorat de l'université de Montpellier III, p. 352.

RIGAUD A. 2001 - Les bâtons percés : décors énigmatiques et fonction possible. Gallia-Préhistoire, 43, p. 101-151.

STREET M., TERBERGER T. 1999 - The Last Pleniglacial and the Human Settlement of Central Europe: New Information from the Rhineland Site of Wiesbaden-Igstadt, Antiquity, 73, 28.

TERBERGER T. 2013 - Le Dernier Maximum Glaciaire entre Rhine et le Danube, un réexamen critique, In : P. Bodu, L. Chehmana, L. Klaric, L. Mevel, S. Soriano et N. Teyssandier (dir.), Le Paléolithique supérieur ancien de l'Europe du Nord-Ouest. synthèses à partir d'un projet collectif de recherche sur le centre et le sud du Bassin parisien, Actes du colloque international (Sens, 15-18 avril 2009), Paris, Société préhistorique française 56, p. 415-443. 